\title{
Religión, política y espectáculo: narrativas del martirio en la primera modernidad
}

\section{Religion, Politics and Spectacle: Narratives of Martyrdom in the First Modernity}

Artículo recibido el 26 de junio de 20I5; devuelto para revisión el 8 de enero de 20I6; aceptado el 24 de febrero de 20I6. http://dx.doi.org/I0.2220I/iie.I8703062e.20I6.109.2578

\section{Carlos Arturo Salamanca \\ Villamizar}

Líneas de investigación

Publicaciones más relevantes
Universidad Nacional de Rosario/Consejo Nacional de Investigaciones Científicas y Técnicas, Argentina, salamanca.carlos@gmail.com

La relación entre territorio, violencia y memoria, especialmente, las condiciones que permiten la emergencia de ciertas narrativas e imágenes acerca de las prácticas de violencia en determinados contextos políticos, sociales e históricos; las representaciones de violencia y los relatos de la alteridad en el contexto de la primera Modernidad en diálogo con el trabajo etnográfico en el marco de una investigación comparativa sobre la cuestión en Argentina, Colombia y Guatemala.

"Saberes geográficos, tensiones de alteridad y teatros del martirio en las cartografías jesuíticas del Nuevo Mundo", Revista Española de Antropología Americana (en prensa); "Das catacumbas às últimas fronteiras: violência, sentido e representação nas marchas do martírio", Topoi. Revista de História I6, núm. 30 (2015): 260-292; "Herejes e infieles: imaginación etnográfica, experiencia histórica y prácticas comunicativas de la alteridad en la obra de De Bry", Revista Brasileira de História das Religióes 19, núm. 7 (mayo, 20I4): 9I-IO6, en http:// www.periodicos.uem.br/ojs/index.php/RbhrAnpuh/index

Resumen Se analizan las representaciones del martirio en el contexto de las guerras de religión, centrándose en sus procesos de producción y circulación. Los vínculos pueden trazarse entre acontecimiento y registro, sitúo el surgimiento del martirologio en un contexto de adelantos técnicos, polémicas religiosas e intensificación de la conquista y la colonización. Después estudio tres martirologios: el primero caracterizado por un dispositivo de glorificación que busca evadir la exaltación sacralizada de los mártires. El segundo que evidencia la tensión entre verdad "teológica" y verdad "histórica", y un tercero en el que la crueldad es puesta en escena sin ambigüedades ni matices. Concluyo estableciendo una síntesis del aporte que este análisis ofrece a las discusiones sobre la violencia y sus representaciones. 
Palabras clave martirio; mártir; memoria; religión; Foxe; Verstegan; Perrissin y Tortorel.

\begin{abstract}
This article analyzes the representation of martyrdom in the context of the Wars of Religion, giving special attention to production and circulation processes. The article examines the links that can be drawn between the events and their chronicling, and the emergence of martyrdom in a context of technical developments, religious controversies and the accelerating process of conquest and colonization. This is followed by the analysis of three particular martyrologies, revealing different representational strategies: the first contrives to glorify without sacralizing the martyrs; the second evidences the tension existing between "theological" and "historical" truth; the third presents cruelty without ambiguities or nuances. The study closes with a summary of the impact the systematic analysis of these works can bring to discussions on violence and its representation.
\end{abstract}

Keywords martyrdom; martyr; memory; religion; Foxe; Verstegan; Perrissin and Tortorel. 
DOI: http://dx.doi.org/10.22201/iie.18703062e.2016.109.2578

\author{
CARLOS ARTURO SALAMANCA VILLAMIZAR \\ UNIVERSIDAD NACIONAL DE ROSARIO/ \\ CONSEJO NACIONAL DE INVESTIGACIONES CIENTÍFICAS Y TÉCNICAS
}

ARGENTINA

\title{
Religión, política y espectáculo: narrativas del martirio en la primera modernidad
}

\section{Polémicas religiosas, violencia y espectáculo}

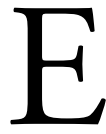
n marzo de 1562, seis semanas después de la firma del edicto del rey de Francia que autorizaba a los protestantes a celebrar sus oficios al exterior de las ciudades, un grupo se había congregado en una granja al interior de la ciudad de Vassy en el principado de Joinville, gobernado entonces por el católico Francisco I de Lorena, II duque de Guisa. En hechos confusos de los que se tienen diversas versiones y que generaron numerosas controversias, las tropas del duque asesinaron alrededor de 50 personas e hirieron a unos I5O. ${ }^{1}$ La llamada masacre de Vassy se produjo en un contexto en el que las políticas represivas contra los protestantes en Francia coexistían con un régimen de inquisición consolidado en España y Portugal, y las consecuencias de la coronación de María Tudor, la Sangrienta, como reina de Inglaterra en 1553 , de la creación en Roma de la Congregación del Santo Oficio en I542, y de las reformas de Calvino y de Lutero. Al funcionar como detonante de estas tensiones, la masacre de Vassy fue el inicio de las guerras de religión en las que católicos y protestantes se envolvieron durante casi tres décadas hasta la firma del Edicto de Nantes en

I. Sobre estas diversas interpretaciones véase Pierre Deyon, "Sur Certaines formes de la propagande religieuse au XVI ${ }^{\mathrm{e}}$ siècle”, Annales 36, núm. I (I98I): I6-25; Henri Hauser, "Un Récit catholique des trois premières guerres de religion les 'acta Tumultuum Gallicanorum”, Revue Historique 108, núm. I (1911): 59-74. 
DOI: http://dx.doi.org/10.22201/iie.18703062e.2016.109.2578

IOO

CARLOS ARTURO SALAMANCA VILLAMIZAR

I598, el último de una serie de tratados de paz. Estas confrontaciones dejaron innumerables e intensas experiencias de terror, desplazamiento y se calcula que entre 2 y 4 millones de muertos. ${ }^{2}$

Casi simultáneamente a las disputas religiosas se produjo una expansión a gran escala de la producción impresa, lo que dio lugar a la aparición y la circulación de un número inusitado de libros, mapas, atlas, volantes, panfletos, gramáticas, muchos de ellos de carácter religioso. ${ }^{3}$ Incluso más que de dos procesos paralelos, algunos autores no dudan en subrayar su estrecha articulación; ${ }^{4}$ el mismo Lutero por ejemplo, afirmaba que "la imprenta [en cuyo desarrollo los protestantes aventajaron a los católicos ampliamente] era el último de los regalos de Dios ya que por medio de ella y la voluntad de Dios las cosas de la verdadera religión pueden ser difundidas $[\ldots]$ en todas las lenguas y sobre la tierra entera". ${ }^{5}$

Desde el inicio mismo de las tensiones, católicos y protestantes representaron en textos, imágenes de acontecimientos y prácticas de violencia religiosa. ${ }^{6}$ Un mayor acceso a los círculos editoriales sumado a la necesidad creciente de elaborar narrativas de los sucesos, convirtieron la impresión en medio y lugar

2. Robert Knecht, The French Religious Wars, I562-I598 (Óxford: Osprey Publishing, 2002), 86 y 91.

3. Para profundizar sobre este fenómeno de difusión véase Michael Baxandall, Painting and Experience in Fifteenth Century Italy (Oxford University Press, I988), 2 y 3; Jeremy Black, "Government, State, and Cartography: Mapping, Power, and Politics in Europe, I650-1800", Cartographica 43, núm. 2 (2008): 95-I05; Chandra Mukerji, "Printing, Cartography and Conceptions of Place in Renaissance Europe", Media, Culture \& Society 28, núm. 5 (2006): 65I-669, http://dx.doi. org/IO.II77/or634437006067020; acerca de la relación entre los protestantes y la producción a gran escala de imágenes y contextos más recientes, véase: David Morgan, Protestant and Pictures. Religion, Visual Culture and the Age of American Mass Production (Nueva York y Óxford: Oxford University Press, 1999).

4. Elizabeth Eisenstein y Gérard Mansuy, "L’Avènement de l'imprimerie et la Réforme", Annales 26, núm. 6 (197I): I355-I382, http://dx.doi.org/I0.3406/ahess.I971.422418.

5. "L'imprimerie est le dernier et le plus important des présents, car par elle et selon la volonté de Dieu, les choses de la vrai religion peuvent être diffusées [...] dans toutes les langues et sur la terre toute entière", Deyon, "Sur Certaines formes", I6 (la traducción es mía).

6. Entre las obras recientes sobre el tema del martirio, véase Susannah Brietz Monta, Martyrdom and Literature in Early Modern England (Cambridge University Press, 2005); Peter Burschel, Sterben und Unsterblichkeit. Zur Kultur des Martyriums in der frühen Neuzeit (Múnich: Oldenbourg, 2004); Thomas S. Freeman y Thomas F. Mayer, eds., Martyrs and Martyrdom in England, ca. I400-I700 (Rochester: Boydell \& Brewer, 2007); John Knott, Discourses of Martyrdom in English Literature, I563-1694 (Cambridge University Press, 1993); Friedericke Pannewick, ed., Martyrdom in Literature: Visions of Death and Meaningful Suffering in Europe and the Middle East from Antiquity to Modernity (Wiesbaden: Reichert, 2004). 
de la confrontación en el cual la violencia se constituyó como un espectáculo necesario de evocar, narrar, conmemorar, y hacer ver. Nobles, sacerdotes y ministros, artistas y mecenas, católicos o protestantes contribuyeron a la elaboración de diversas representaciones y narrativas sobre la violencia. En ese contexto, la figura del martirio adquirió un lugar preponderante.

El martirio es una puesta en escena polisémica, que combina la práctica judicial del interrogatorio, el ritual religioso y el acto espectacular de los juegos de circo de la Roma imperial.7 El mártir, reivindicado como instrumento de la imitación de Cristo, "habla" a Dios, a los testigos, a sus victimarios y a sus pares (a otros que murieron como él, a otros que morirán como él) a quienes se une por el mismo acto, constituyendo una comunidad en torno al acontecimiento.

El martirio reúne en las figuras de victimario y de víctima el arquetipo de dos individualidades extremas por la naturaleza misma del acto de matar y ser matado y la significación que se le atribuye. No obstante, por medio de la representación, victimario y víctima se funden, cada uno, en dos comunidades de sentido contrapuestas que se extienden tanto en el espacio (hacia sus contemporáneos) como en el tiempo (hacia quienes los precedieron, hacia aquellos que están por venir).

La potencia del martirio reside no sólo en la reproducción del rito primordial del sacrificio, sino en la proyección del discurso nuevo que de allí emerge. Es en las prácticas de personas singulares, en lugares específicos y a través de medios concretos que tal acto tiene lugar; pero es por medio de su vinculación con redes más amplias de significación que el acto sagrado toma forma.

\section{El martirologio como género de representación de la violencia}

El interés en la representación del martirio no era nuevo y se constituyó a partir de la recuperación de distintos elementos de varias épocas y tradiciones, entre los que sobresalen, por una parte, legados medievales como tropos y temáticas provenientes de obras como la Masacre de los inocentes (fig. I) o leyendas como santa Úrsula y su martirio a manos de los hunos. ${ }^{8}$ Por otro

7. Frank Lestringant y Pierre-François Moreau, "Overture", Martyrs et martyrologes, Revue de Sciences Humaines, 269 (Presses Universitaires du Septentrion, 7-13, y Frank Lestringant, "Témoignage et martyre: donner à voir, donner à croire (XVI ${ }^{\mathrm{e}}$-XVIII ${ }^{\mathrm{e}}$ siècles)", en Martyrs et martyrologes.

8. Acerca del uso de las imágenes como propaganda luterana, véase, por ejemplo, Max Geisberg, The German Single Leaf Woodcut I500-I5so (Nueva York: Walther L. Strauss, 1974). 
DOI: http://dx.doi.org/10.22201/iie.18703062e.2016.109.2578

IO2

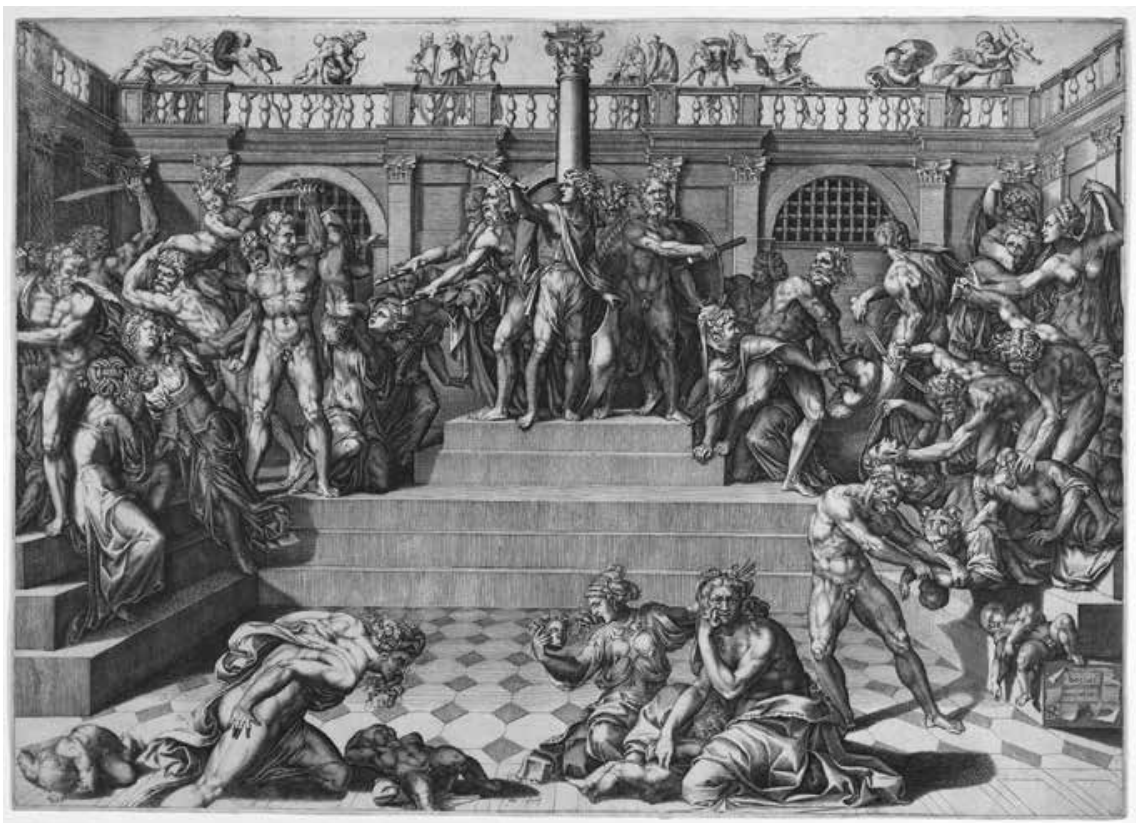

I. Marco Dente da Ravenna (atribuido), a partir de Baccio Bandinelli, Masacre de los inocentes, s.f., $39.8 \times 56.5 \mathrm{~cm}$. (C) The Metropolitan Museum of Art - www.metmuseum.org. The Elisha Whittelsey Fund, 1949 .

lado, la idea del mundo como un teatro, ${ }^{9}$ que emergió en la época clásica, se estaba expandiendo en diversas esferas de la representación. Estos elementos dieron lugar a la aparición de un nuevo género para manifestar la violencia, el martirologio, teatral, didáctico, emotivo y con un gran potencial de difusión y movilización.

El martirologio (del griego martyr, "testigo", y logos, "discurso") inscribe el suceso del martirio en redes específicas de significación y lo dota de atributos como la sacralidad y la trascendencia. De esta forma, contribuye a la constitución de marcos interpretativos para la comprensión de las controversias, las tensiones y las violencias religiosas. En contextos histórico-políticos, como el que analizo, en los que se enfrentan versiones contrapuestas, el martirologio

9. Sobre esta temática véase Lina Bolzoni, Giulio Camillo. La idea del teatro, trad. Jordi Raventós (Madrid: Siruela, 2006); Frances A. Yates, The Art of Memory. Selected Works (Londres y Nueva York: Routledge, 1999). 
propone además una narrativa y una mirada particular y localizada de lo acontecido. Los martirologios se caracterizan también por tensiones morales que se manifiestan en lecturas contrapuestas; como afirma El Kenz; aquel que de un lado es visto como héroe de la fe, del otro puede ser considerado parricida. ${ }^{\text {Io }}$ Aunque se produjeron martirologios bajo otros formatos como conjuntos de frescos realizados en iglesias, aquellos a los que me refiero aquí aparecieron en libros impresos impulsados por la expansión editorial.

El martirologio es una obra "abierta", dinámica y en permanente actualización, que se modifica con cada nueva edición para insertarse en los panoramas locales en busca de mayor eficacia al aumentar el número de ilustraciones, incluir prólogos o epílogos distintos o traducir los textos a diversos idiomas "más accesibles"; no obstante, más que hablar exclusivamente de obras transformándose en función de las audiencias, se trata de un proceso bidireccional en el cual los martirologios también "producían" las audiencias en torno a distintos sentidos; sensibilidades y temores son resultado tanto de la acción colectiva como personal; al tenerse en cuenta esta tensión, los martirologios pueden pensarse como conjuntos heterogéneos en donde la copia, la referencia, la síntesis, y la edición priman por sobre el acto creativo puro y la estricta autoría individual. ${ }^{I I}$ Se trata de obras frente a las que la noción moderna de autor resulta inestable, no sólo por aquello que se entiende como tal sino porque en su producción —obra "abierta", dinámica y en permanente actualización— participan varios agentes.

$\mathrm{Al}$ mantener una relación poco transparente con los acontecimientos, los martirologios requieren ser estudiados en función de los contextos históricopolíticos en los que se insertaron. Al retomar cada martirologio como unidad de estudio, mi análisis se despliega en tres aspectos; primero me detengo en el estudio de los procesos de producción, posteriormente analizo conjuntos representativos de imágenes seleccionadas para describir temáticas recurrentes y estrategias compositivas; en tercer lugar analizo las formas en que cada martirologio "media" entre las audiencias y los acontecimientos de violencia, proponiendo interpretaciones, significaciones y sentidos específicos. Antes de hacer el análisis son necesarias algunas precisiones conceptuales y metodológicas.

Io. David El Kenz, "Les Usages subversifs du martyre dans la France des troubles de religion: de la parole au geste", Revue de Sciences Humaines, núm. 269 (2003), 43.

II. Mukerji, "Printing, Cartography and Conceptions", 652. 
DOI: http://dx.doi.org/10.22201/iie.18703062e.2016.109.2578

IO4

CARLOS ARTURO SALAMANCA VILLAMIZAR

\section{Precisiones conceptuales y metodológicas}

Hayden White subrayó el papel central de la narración en la construcción de la historia y señaló la porosidad de las fronteras entre las formas y el contenido de la narración histórica. ${ }^{\mathrm{I2}} \mathrm{El}$ análisis dialéctico del acontecimiento y de su registro requiere asociar las significaciones y los sentidos a las formas materiales que las transmiten, reconociéndolas como unidad de sentido y como conjunto representacional en torno al cual se dan múltiples mediaciones. ${ }^{13}$ Por cesión del martirologio el mártir trasciende el círculo de los testigos, interpela a una comunidad más amplia y, convertido en arquetipo moral y espiritual, se proyecta en un horizonte espacio-temporal más amplio. ${ }^{14} \mathrm{El}$ martirologio reconstituye el martirio como acontecimiento trascendente y lo incorpora en una figuración narrativa sagrada. ${ }^{\mathrm{IS}}$

Trabajos recientes han subrayado que los martirologios tendieron a reproducir una imagen homogénea y simplificada de las comunidades religiosas ocultando, entre otros, sus particularidades regionales o locales, sus diferencias internas, así como la complejidad de las relaciones interconfesionales. ${ }^{16} \mathrm{No}$ obstante, análisis más recientes han señalado diversos campos de investigación que no se restringen a estudiar la veracidad de las narrativas y que se han demostrado fecundos.

I2. Hayden White, "El pasado práctico", en Verónica Tozzi y Nicolás Lavagnino, Hayden White. La escritura del pasado y el futuro de la historiografia (Buenos Aires: Eduntref, 20I2), 19-40, 32 y 38.

13. Roger Chartier, Escribir las prácticas. Foucault, De Certeau, Marin (Buenos Aires: Manantial, 2006).

I4. Diversos autores han mostrado que ni los misioneros ni la Iglesia mantuvieron el monopolio del uso de los mártires y de las reliquias. Véase, por ejemplo, Charlotte de Castelnau-L’Estoile, "Compartir las reliquias. Indios tupíes y jesuitas frente a los huesos de un misionero chamán en el Brasil de inicios del siglo XvII", en Guillermo Wilde, ed., Saberes de la conversión. Jesuitas, indigenas e imperios coloniales en las fronteras de la cristiandad (Buenos Aires: SB, 20II), 225-250; Kenneth Maxwell, "The Spark: Pombal, the Amazon and the Jesuits", Portuguese Studies I7 (200I): I68-I83; Pierre-Antoine Fabre, "Reliquias romanas en México, historia de una migración”, en Wilde, Saberes de la conversión, 205-224.

I5. Jean-Philippe Pierron, "La Dimension figurative du témoignage: l'exemple des premières martyres chrétiens", Revue de Sciences Humaines 269 (2003): 15-32, 3I.

I6. Al respecto, véase por ejemplo, Paul Quinn, "Richard Woodman, Sussex Protestantism and the Construction of Martyrdom”, en Art, Literature and Religion in Early Modern Sussex: Culture and Conflict, eds. Matthew Dimmock, Andrew Hadfield y Paul Quinn (Farnham y Burlington: Ashgate, 20I4), 195-220. 
En efecto, el análisis de la relación entre prácticas de violencia y representación ha tenido un crecimiento exponencial en los últimos años. ${ }^{17} \mathrm{Al}$ partir de investigaciones sobre la teatralización de la política ${ }^{18}$ y el papel del lenguaje $y$ discurso en las relaciones de poder ${ }^{19}$ me intereso en los martirologios tanto como medios así como en sus mediaciones; para glosar a Clifford Geertz, me propongo la exégesis de la violencia hecha una y otra vez con el insistente vocabulario ya no sólo del ritual sino de su representación. ${ }^{20}$

Diversas investigaciones recientes se han interesado en la influencia del desarrollo exponencial de la imprenta en las guerras de religión ${ }^{21} \mathrm{y}$ al orientarse a indagar en aspectos como la construcción social del sentido, se han detenido en el estudio de las representaciones en tanto componentes fundamentales de los procesos históricos y elementos constructores del orden social. ${ }^{22}$

Al hablar de mediaciones me refiero por una parte, al proceso de comunicación mediante el cual se imaginan, preparan, elaboran y ponen en circulación representaciones de la violencia por medio de los martirologios; asimismo, aludo a las formas en que quienes son sus destinatarios se relacionan con los acontecimientos de violencia mediante las narrativas que se hacen de aquéllas. En uno y otro caso me propongo analizar las relaciones sociales de producción y uso de discursos y representaciones en contextos particulares.

17. Stephen Eisenman, The Abu Ghraib Effect (The University of Chicago Press, 2007); Arthur Kleinman y Joan Kleinman, "The Appeal of Experience: The Dismay of Images: Cultural Appropriations of Suffering in Our Times”, Daedalus I25, núm. I (1996): I-23; José Emilio Burucúa y Nicolás Kwiatkowski, "Cómo sucedieron estas cosas". Representar masacres y genocidios (Buenos Aires: Katz, 20I4).

I8. Georges Balandier, Le Pouvoir sur scène (París: Fayard, 2006[1980]); Clifford Geertz, Negara. The Theater State in Nineteenth Century in Bali (Princeton University Press, 1980); Clifford Geertz, "Centros, reyes y carisma: una reflexión sobre el simbolismo del poder", en Conocimiento local, trad. Alberto López Bargados (Barcelona: Paidós, I994[1977]), I47-I72.

19. Geertz, "Centros, reyes y carisma”, 152.

20. Geertz, Negara, IO2.

2I. Véase Gabriele Haug-Moritz y Lotar Schilling, dirs., Médialité et Interprétation contemporaine des premières guerres de Religion (Berlín, Múnich y Boston: Walter de Gruyter, 20I4).

22. Roger Chartier y Jean Martin, Histoire de l'Édition française (París: Fayard, 1989); Burschel, Sterben und Unsterblichkeit, 220; Paul-Alexis Mellet y Jérémie Foa, "Le Bruit des armes: mises en formes et désinformations en Europe pendant les guerres de Religion, I560-I6IO", en Paul-Alexis Mellet y Jérémie Foa, eds., Actes du Colloque International, Tours, 5-7 novembre, 2009; David El Kenz, "La Mise en scène médiatique du massacre des huguenots au temps des guerres de Religion: théologie ou politique?", Sens Publique Revue Web, 24 de septiembre de 2006, consultado el I8 de enero de 20I6, www.sens-public.org/article333.html?lang=fr. 
DOI: http://dx.doi.org/10.22201/iie.18703062e.2016.109.2578

I06

CARLOS ARTURO SALAMANCA VILLAMIZAR

En los estudios contemporáneos sobre la representación de la violencia, uno de los ejes más prolíficos es el de los estudios de la memoria. Desde diversas perspectivas desarrolladas, muchas de ellas a partir de los trabajos de Michel Foucault, ${ }^{23}$ se ha reconocido la mediación como característica propia de las prácticas de la memoria y para referirse a "los medios" se ha hecho uso de distintas definiciones como "lugares", 24 "vehículos", 25 "artefactos", ${ }^{26}$ "tecnologías", 27 o "instituciones de poder". ${ }^{28}$ Estas denominaciones resultan insuficientes por tender a reproducir la idea dicotómica de emisores/receptores y a focalizar la observación en una de las partes, por detenerse exclusivamente en el medio o en su naturaleza, por no dar cuenta de las relaciones y de los vínculos que se establecen entre el medio y los agentes que intervienen, por ignorar que la producción del medio tiene un destinatario con el cual se busca, pretende o supone una relación o un vínculo específico, o por pasar por alto que las relaciones entre los actores intervinientes deben ser integradas al análisis del medio mismo.

Para mi análisis del martirologio como género de representación de la violencia religiosa he seleccionado tres obras: Acts and Monuments de John Foxe (I563), ${ }^{29}$ los 40 cuadros de Jacques Perrissin y Jean Tortorel $\left(\mathrm{I}_{570}\right)^{30}$ y El teatro de las cruel-

23. Entre otros, a partir de los conceptos de formación discursiva y dispositivo, véase Michel Foucault, Archeologie du savoir (París: Gallimard, 1969).

24. Pierre Nora, Les Lieux de mémoire (París: Gallimard, 1984), xIx y ss.

25. Paul Ricoeur, La memoria, la historia, el olvido, trad. Agustín Neira (Buenos Aires: Fondo de Cultura Económica, 2008), 498.

26. Javier Alejandro Lifschitz y Sandra Patricia Arenas Grisales, "Memoria política y artefactos culturales", Estudios Políticos, núm. 40 (2012): 98.

27. Karen Till, "Artistic and Activist Memory-work: Approaching Place-based Practice", Memory Studies I, núm. I (2008): IOI.

28. Benedict Anderson, Comunidades imaginadas, trad. Eduardo L. Suárez (México: Fondo de Cultura Económica, 2000), 228.

29. El análisis de la obra de Foxe que aquí se presenta ha sido realizado a partir de la edición de 1563 , editada en Londres por John Day y puesta en línea en el marco del proyecto "John Foxe" de la Universidad de Sheffield, https://www.johnfoxe.org/index.php? realm=info\&type=about \&gototype $=$ \&static $=$ works

30. Jacques Perrissin y Jean Tortorel, Premier Volume contenant quarante tableaux ou histoires diverses qui sont mémorables touchant les guerres massacres et troubles advenus en France en ces dernières années. Le tout recueilli selon les tesmoignage de ceux qui y ont esté en personne, et qui les ont veus, lesquels sont pourtrais à la verité (s.i., I570). 
DOI: http://dx.doi.org/10.22201/iie.18703062e.2016.109.2578

RELIGIÓN, POLÍTICA Y ESPECTÁCULO

dades de los heréticos de nuestro tiempo, en adelante El teatro de Verstegan. ${ }^{3 \mathrm{I}}$ He escogido estos martirologios en razón de su utilización de texto e imagen, por ser éstos tanto de origen protestante como católico, por estar inscritos en el despliegue del auge de la imprenta y por ser contemporáneos, lo cual permite el análisis transversal.

John Foxe, Acts and Monuments y el heroismo del héroe sin rostro

Acts and Monuments también conocido como el Book of Martyrs, del inglés John Foxe, es una publicación en la que se describen los martirios de los protestantes en Inglaterra a manos de los católicos en los acontecimientos desatados con la llegada de María I a la Corona que llevarían a la hoguera a más de 300 protestantes y al exilio a cientos de ellos. Es un trabajo de recopilación de poemas, cuentos, obras de la cultura popular, bulas papales y documentos oficiales que incluía material de archivo impreso, testimonios de testigos y pasajes de otros martirologios como el de Jean Crespin, publicado previamente. ${ }^{32}$

La obra se caracteriza, en primer lugar, por su proyección simultáneamente teatral y política, en función de la doble acepción del vocablo inglés acts. Por una parte, opera en un registro dramático y teatral (los actos) de las experiencias de suplicio. Por otra, en un registro histórico-político (las actas) en el que el martirio emerge como una acción pública deliberada, religiosa y política, planificada y ejercida colectivamente. ${ }^{33}$

La segunda característica del martirologio de Foxe es el interés compilatorio como criterio para dar forma a la obra; fue uno de los más difundidos y leídos de su tiempo con cuatro ediciones en inglés en el breve lapso de 20 años (I563, I570, 1576 y I583), antecedidas por dos obras preliminares en latín publicadas en I554 y I559. Ya desde 1563, año en que se integraron a la edición 53 grabados, los ejemplares del libro se dispusieron para el público en iglesias, escuelas, palacios y librerías privadas, ${ }^{34}$ mientras que circulaban como préstamo entre miembros

31. Richard Verstegan, Théatre des Cruautés des hérétiques de notre temps (París: Chandeigne, I995[I587]), consultado el I2 de marzo de 20I4, http://gallica.bnf.fr/ark:/I2I48/bpt6kio40506g.

32. Jean Crespin, Actes de Martyrs (Ginebra: imprenta de Jean Crespin, 1554).

33. Dominique Weber, "Dieu est-il anglais? La question du martyre dans la philosophie de Thomas Hobbes", Revue de Sciences Humaines, núm. 269 (2003): 207-230.

34. Isabelle Fernandes, "Les Représentations du martyr dans The Acts and Monuments de John Foxe”, Revue de Sciences Humaines, núm. 269 (2003): I34-I5I. 
DOI: http://dx.doi.org/10.22201/iie.18703062e.2016.109.2578

IO8

CARLOS ARTURO SALAMANCA VILLAMIZAR

de la corte. El Parlamento inglés adquirió ejemplares de la versión de 1570 para disponerlos en espacios públicos, mientras que la siguiente versión recibió la aprobación oficial, y se ordenó que el libro fuera colocado en iglesias de toda Inglaterra. Para reducir el precio del libro y facilitar una mayor distribución, la edición de 1576 se realizó en un papel más económico y en un formato más pequeño. Estas medidas hicieron de Acts and Monuments una obra popular, difundida rápidamente por toda la isla y luego por Europa. ${ }^{35}$ La obra contribuyó a la formación de una conciencia nacionalista inglesa forjada en torno a una identidad protestante y en oposición al catolicismo romano ${ }^{36}$ y fue fuente de manifiestos políticos de matriz religiosa al menos hasta finales del siglo XVII. ${ }^{37}$ En las procesiones londinenses en I680, por ejemplo, al pontífice se le representó sentado, con un pie en el cuello de un monarca postrado a sus pies, tal como había sido representado por Foxe un siglo antes..$^{8}$

En tercer lugar, el trabajo de Foxe ejemplifica la manera acelerada en que las imágenes adquirieron protagonismo en la representación de la violencia derivada de los conflictos religiosos. Para la década de 1570 su eficacia como herramienta para facilitar el acceso a los martirologios era reconocida por protestantes y católicos por igual; de hecho, años antes Lutero había separado claramente la idolatría y los excesos sacrílegos del uso pedagógico de las imágenes. ${ }^{39}$ En esta línea, la primera edición de Acts and Monuments se publicó en latín y sin imágenes lo que restringía su acceso, pero a partir de la segunda edición se fueron incorporando cada vez más imágenes hasta que en la edición de I570 se contaban más de IOO grabados. ${ }^{40}$

Una cuarta característica del martirologio de Foxe tiene que ver con la emergencia de las tensiones entre lo individual y lo colectivo. De firme fe protestante, cuando Foxe cumplió 35 años ya había publicado varios tratados políticoreligiosos, traducido a Lutero e intentado evitar — sin éxito— la ejecución de

35. David Loades, "The Early Reception”, John Foxe's Acts and Monuments On-line. HRI, consultado el 4 de julio de 20I3, www.johnfoxe.org.

36. John King, "Introduction", en Foxe's Book of Martyrs. Select Narratives (Oxford University Press, 2009), XI-XL.

37. Loades, "The Early Reception", s. p.

38. Recientemente se ha puesto en cuestión la influencia protestante en la identidad inglesa y la aceptación a ciegas de la oposición entre catolicismo e identidad británica. Véase Christopher Highley, Catholics Writing the Nation in Early Modern Britain and Ireland (Oxford University Press, 2008).

39. Deyon, "Sur Certaines formes", 17.

40. Fernandes, "Les Représentations du martyr”, I47. 
protestantes en la hoguera. Al igual que para cientos de protestantes, el nombramiento de María I le significó el exilio. Foxe empezó un periplo por Amberes, Róterdam, Fráncfort y finalmente Estrasburgo, en donde inició su trabajo sistemático en la historia de los mártires. En efecto, el martirologio para Foxe representaba un asunto personal. Acts and Monuments es también el resultado de una empresa colectiva. Entre I554 y 1559 personajes político-religiosos como John Bale o Edmund Grindal que reunían historias de mártires y martirios impulsaron a Foxe a recopilar y difundir información sobre la violencia religiosa contra los protestantes. Entusiasmados con la primera edición, los familiares de los martirizados y muchos otros protestantes agradecieron a Foxe ofreciéndole testimonios de testigos directos, cartas de los mártires y otros recuerdos personales que se utilizarían en las ediciones siguientes.

En quinto lugar, el martirologio de Foxe aborda las tensiones por la veracidad y supremacía de la fe mediante múltiples operaciones compositivas. Para la construcción de la proyección histórica el autor vinculó a los mártires protestantes con los primeros cristianos perseguidos por el imperio romano evocando similitudes en las formas de violencia ejercidas. Simultáneamente, la alianza establecida por ese entonces entre la Iglesia católica y la monarquía española permitió ubicar a los católicos en el lugar de los victimarios, emparentarlos con los verdugos de los primeros cristianos y por extensión del mismo Jesucristo.

Foxe recurre a lecturas de opuestos dicotómicos para la crítica moral en varios grabados; en uno de ellos se presentan varias escenas en las que los papas aparecen con joyas y trajes lujosos rodeados de reyes y nobles en palacios y plazas ejerciendo con orgullo su poder, político o "temporal" que de acuerdo con la doctrina protestante era privilegiado por encima del poder espiritual (fig. 2). Estas imágenes reproducen la idea de la riqueza y el poderío político de la Iglesia católica, presente desde los inicios de la Reforma protestante -incluso desde la Edad Media - de la mano de los primeros cuestionamientos que hiciera Lutero en Wittenberg, en I517, respecto a la venta de las indulgencias.

La crítica moral también se manifestó bajo la forma de la narración en primera persona. En 1560 Foxe publicó de forma anónima la narración de un ficticio anticristo papal, en la que éste describía cómo había conquistado el poder y abusado del mismo. ${ }^{4 \mathrm{I}} \mathrm{A}$ Solemne contestation of divers Popes estaba compuesto de citas de bulas papales y otros materiales con los que se pretendía una apariencia 
DOI: http://dx.doi.org/10.22201/iie.18703062e.2016.109.2578

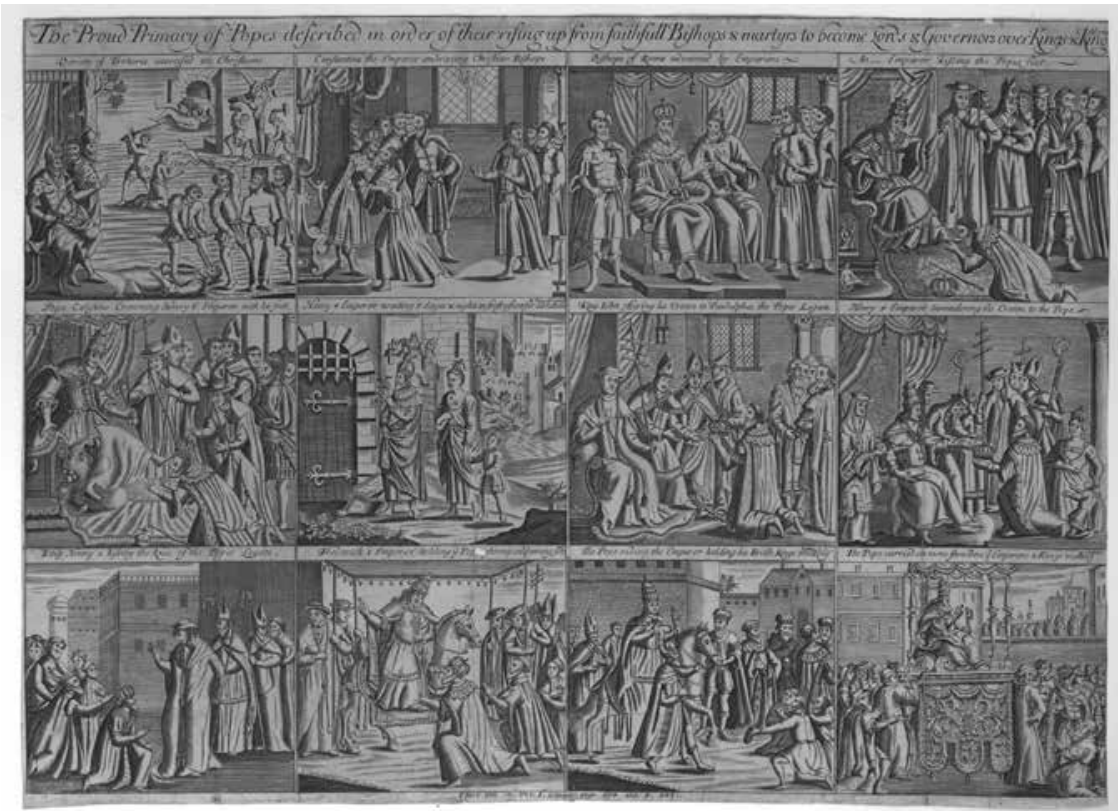

2. John Foxe, Descripción de la primacía del orgullo papal, grabado, $39 \times 55 \mathrm{~cm}$, tomado de Acts and Monuments, vol. I, I684, encarte entre los folios 884 y 885 . Londres, British Museum, núm. ref. 1994,0515.I2. (C) The Trustees of the British Museum CC-BY-NC-SA-4.O

de autenticidad. La publicación se imprimiría nuevamente meses después como parte del Acts and Monuments.

El grabado Descripción de la primacía del orgullo papal apareció en las ediciones de 1576 y 1583 e ilustra la incorporación del testigo activo; evocando obras emblemáticas, ${ }^{42}$ en la imagen aparece el rey sentado y observando los vejámenes contra los protestantes: en primer plano, un hombre arranca a otro un ojo, allí otro es latigado, un poco más allá, un tercero es decapitado (véase el primer recuadro de la figura 2). Al ilustrar los juegos de escala, esta imagen se publicó tanto de manera individual en las ediciones de 1576 y 1583 como integrada a

42. Entre otras, "El martirio de los diez mil cristianos", de Alberto Durero, I508, Museo de Historia del Arte de Viena y "Passional Christi und Antichristi", de Cranach, el Viejo, I52I, Biblioteca Nacional de Dinamarca y Copenhague, consultado el 20 de enero de 20I6, www.kb.dk/ en/nb/tema/webudstillinger/luther/passion/index.html. Para un análisis de la obra de Durero, véase: Burschel, Sterben und Unsterblichkeit, 28. 
una obra más amplia. La presencia de un hombre al ser devorado por leones y de otro crucificado hace del rey un testigo partícipe también de las violencias del pasado, de aquellas ejercidas por Roma contra los primeros cristianos. Una misma estrategia se utilizaría para convertir en testigos partícipes al papa y a los integrantes del clero; aunque sin ser protagonistas estos personajes se incorporan en tanto testigos partícipes en la interpretación sobre la violencia.

La última composición de la obra de Foxe es la síntesis de escenas en las que la crueldad y la violencia se exhiben en unidades autónomas. Ésta puede constatarse en imágenes que incorporan, refieren y citan otros grabados presentes en la misma obra como El emperador Enrique III humillado con su familia a las puertas de la ciudad de Canossa ${ }^{43}$ o El papa Alejandro pisando el cuello de Federico, el emperador. ${ }^{44}$ Estas imágenes dan lugar a mensajes que se hacen explícitos por asociación como la responsabilidad del emperador romano en la crueldad ejercida en contra de los primeros cristianos, o sus vínculos con la Iglesia católica. La figura 3 muestra, a la manera de un esquema descriptivo y didáctico, más de 30 prácticas de violencia en contra de cristianos primitivos que son aperreados, desmembrados, desollados, descuartizados, quemados vivos en hornos, casas, piras, parrillas y calderos, colgados o apedreados hasta la muerte. En continuidad con lo ya referido con respecto al primer recuadro de la figura 2, en este caso, la presencia de las figuras de papas y reyes a los costados de la imagen propone una síntesis necesaria para producir tres sentencias articuladas: el emperador y la Iglesia católica son figuras intercambiables, unos y otros ejercen las mismas formas de violencia, unos y otros atacan a los cristianos verdaderos (fig. 3).

Introduzco esta parte refiriendo la rapidez con la que se incorporaron las imágenes a la obra de Foxe; queda por analizar la manera en que se escenifica el martirio sin recurrir a la exaltación del mártir como tal ni dar lugar a interpretaciones erradas o idolátricas, una preocupación muy presente entre los protestantes.

Primero, los escenarios en los cuales los creyentes son martirizados son genéricos lo que impide una identificación de los creyentes con lugares específicos. Segundo, se utilizan las mismas imágenes para ilustrar el martirio de personajes diferentes, limitando la identificación popular con determinados mártires mediante imágenes específicas. La flexibilidad del vínculo entre el mártir y la

43. Foxe, Acts and Monuments, L. IV, fol. $4 \mathrm{I}$.

44. Foxe, Acts and Monuments, L. IV, fol. 56. 
DOI: http://dx.doi.org/10.22201/iie.18703062e.2016.109.2578

II2

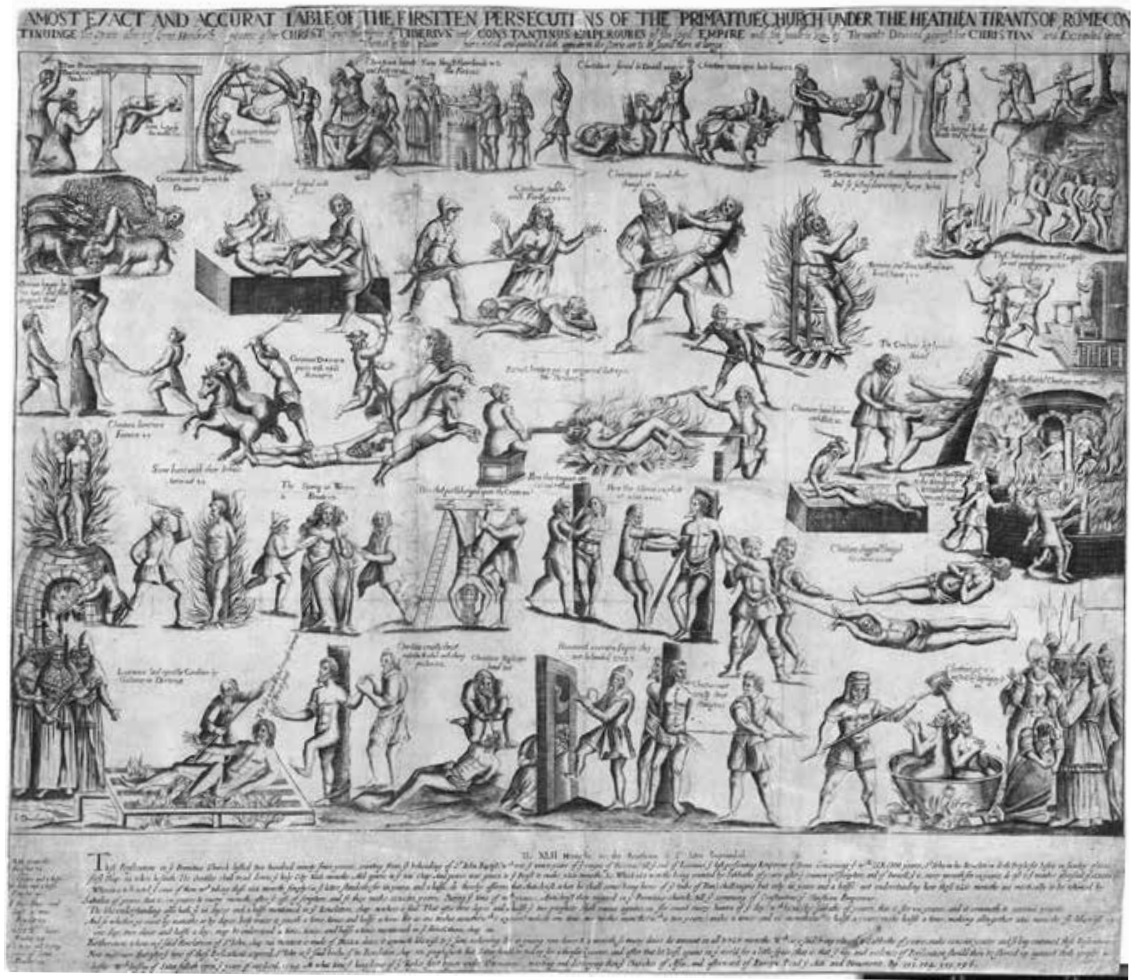

3. Anónimo, según John Droeshout, Una tabla más precisa y certera sobre las primeras diez persecuciones de la Iglesia primitiva bajo los tiranos paganos de Roma, grabado posterior a la edición de 1563, 3.98 $\times 4.92 \mathrm{~cm}$, tomado de John Foxe, Acts and Monuments, Londres, British Museum, núm. ref. I868, 0808.I3419. (C) The Trustees of the British Museum CC-BY-NC-SA-4.O.

representación de su martirio se observa también en imágenes que cambian con las ediciones. Una misma imagen (fig. 4) ilustra las dos operaciones. En el primer caso, esta imagen se utilizó para ilustrar no sólo el martirio de Christopher Shoomaker sino al de otros protestantes como Mill, Hytten y Stilman; repitiéndose siete veces en la edición de 1570 y nueve en la de 1583 . En el segundo, esta misma imagen, que se utilizó para ilustrar el martirio del obispo Farrar en la edición de 1563 , fue reemplazada por otra en la edición de 1570 . 
K. Hen, 8. Williwn Sweeting, fames Brewfer, and Chriflopher Shoonaker, Marigrs.

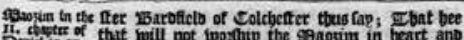

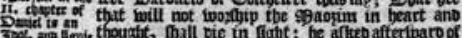

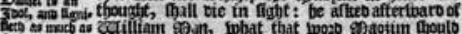

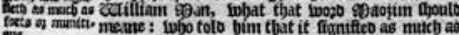
the matifing $\Theta_{00}$, to twit the sutrament of the Altar.

3ttan, that be hab unach conferente fitth gentrp jert, againt oblations ano 3 mages, ano tyat tt was better betioluse monep woticb was giben to the
pwise, than that that was offereo in pilgrtmage.

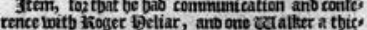
ker offaint elements, concerning bibers fatb mat: ters of pilgrimage, offering to 3 mages, ivosflip ping of sainte, ano tbe sacrament of the ailear.

pung of gaints, ano tbe sacrament of the aitar.

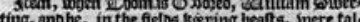
ting, anobe, in the ficlos the ping bealts, were tal king together of the facrament of the 2 ozos boobs

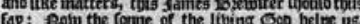
far: fow toe fome of the living Oco beipe us. ner, foto alturigbtic $\sigma_{00}$ to 00.

Ino tfus babe pou tbe caules littetuife ano crimes lapo atainf 3 ames 25 sctofter, upontinbich be imtith

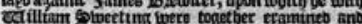
sonocumeb. Ében betng aftite, as the itounith mant nee is, lphetber be bab anp caule lwbe bee thould not be abjutoger for relapice ; be truthing to finoe fabout ano grace in fubrnitting bimselfe, faib, that bee fabuntttes bim to the mercio of Alurightie $\sigma_{00}$, ano to the fabourable goonetife of bim bis 3ubge.

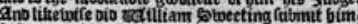
felfe; trutting bettite that thes thoulo finoe rom fabour ant relicfe it this bumble frubjecting them feloes unto theic gooutetie.

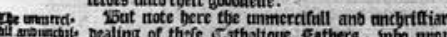

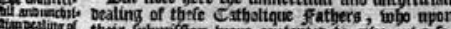

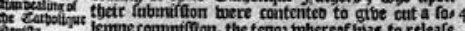
lemme comnifiton, the tenos whercof toas to releaf ant paroour tbem frain the fentence of excoinumunt cation, wibceutro tbeg bro incurre : But unmed atelgater upon toe fante, the 2bibop, all this net

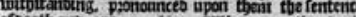

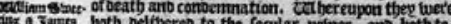

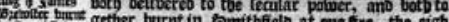

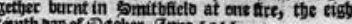
- Chriftopher Shoomaker Martyr.

$T$ D tuefe blefreoraints befoye nanneb, be will alfo this 3 finoe bicfely in the

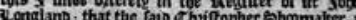

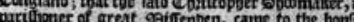
of Jobn sur, anb after of to bun out of a littie 5 solke the wozos which Chriet 60 fpalse to bis mirecinleg. In thas conmung to hit boure about foute times, at cocre time hee reas bim not to be becerven in the paiefts celebstion of Sgatie, ano octiaring that it mas not the rante bers pieicut boop of chitit, as the jarielts biophutas. he; bet in fubetante breao, bearng the remem bjance of Chrift: and taught bim moseober, that pil. grimage, woskipving ano cetting up Canoles to

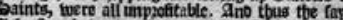
Kobn oar baing taugbt be tuis enjitopter, anval

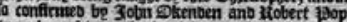
was byougbt to the anotoleste of the fame tDo arine. Egus nach bietely 3 fnoc in tbat liegrilte: concenting Cypapser sywinatier : oeclarin

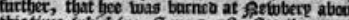

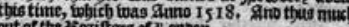
out of the jiesiofors of $L$ onbori.

If furning obet the 3aegifters ano zaerojos of

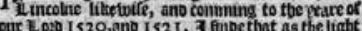
our L $0: 01520$, ano $152 \mathrm{I}$. 3 finbe tbat as the ligbt of the Eofpell tegan niope to appeare, anto tbe unm,
ber of the pzofetiogs to grotw, to tbe bebrnencie of perfecution, ant ititre of toe 1 sithops, begun atio to enereare. cabertupon enfued great perturbatt on ano griebous affitiotion in bivers anb finnogie quarters of this titealme, efipectallp abcut isnct ingbam ditre ano gameribom, varbyloge, Dents Petwberp, in the Dioctie of nonbon, in eficer, Colcbetter, Euffolthe, ano foztbolke, ano otber flaces ntce. Suno this was befoze the naine of Lu Eoce was bearo of in toece ccumtries among the peo. phe.

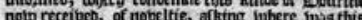
Churction

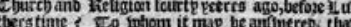
therstime? Eo mojom it map be aurfwerebs tbat

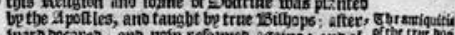

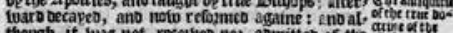
though it was not retribeo no3 aomitteb of the sicistil jaopes clergie befose 3 uthers time, neitber net is; pet it was recetbero of other, in tobefo bearts it pleafor the Lozo fecretto to wojke, ano that cf a

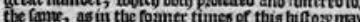
appeare. Andif tbes tounte this botrine be ? neis that it was not bearo of befose Luthers time, bot then came farb great perieruticn brfore entbers time bere in englano? zi theíe bere of the lams profeftion ibbicb tbee were of, then luas tbeic cruel tie unirearionable, to to periecute thetr ofune Cattio isque fraternitp. Ino if tbee twere otberwife, bolo

I The burning of Chrillopher Shoomaker.

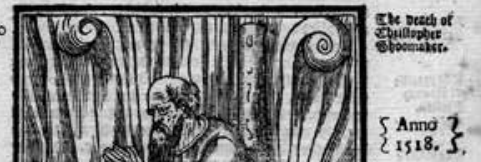

so

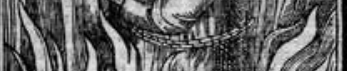

$\left\{\begin{array}{l}\text { Annd } \\ 1518 .\end{array}\right.$

4. John Foxe, El mártir protestante Christopher Shoomaker, grabado en madera, tomado de John Foxe, Acts and Monuments, edición posterior a la de 1563, fol. 3I. Londres, British Museum, núm. ref. I871, I209.64. (C) The Trustees of the British Museum CC-BY-NC-SA-4.O. 
DOI: http://dx.doi.org/10.22201/iie.18703062e.2016.109.2578

II4

CARLOS ARTURO SALAMANCA VILLAMIZAR

En tercer lugar, no existe una relación sacralizada con las imágenes: las mismas se alteraban, modificaban y editaban en cada nueva edición. ${ }^{45}$ La ya referida del protestante Christopher Shoomaker se utilizó para ilustrar la quema del obispo Farrar como repetida tres veces en el sentido horizontal para representar la muerte de otros protestantes.

Finalmente, lejos de orientarse a un protagonismo demasiado explícito del mártir las imágenes representaban martirios colectivos en escenas en las que se incluyen tres o más mártires, en momentos y lugares diferentes en una misma imagen, o incorporaban a la muchedumbre resaltando la dimensión colectiva del acontecimiento (fig. 5).

En síntesis, las principales características de la obra de Foxe son: la proyección simultáneamente teatral y política, la incorporación del criterio editorial en la forma misma de la obra, la importancia creciente atribuida a las imágenes, las tensiones entre lo individual y lo colectivo, y el despliegue de mecanismos representacionales mediante las cuales se pone en escena el martirio sin exaltar al mártir como tal. Aunque también elaborada desde "el punto de vista protestante", en su obra, Jacques Perrissin y Jean Tortorel prefirieron enfrentarse a otro desafío: contribuir a comprender "la verdad histórica".

\section{La historia en escena, los 40 cuadros de Jacques Perrissin y Jean Tortorel}

Jean Perrissin fue un pintor protestante lionés que se exilió en Ginebra a finales de la década de 1560 . Allí conocería a Jacques Tortorel, también francés, con quien sería contratado por dos empresarios textiles holandeses para la realización de imágenes sobre las guerras de religión en Francia entre 1562 y 1570. El contrato para la realización de la obra, firmado en 1569 , establecía la dedicación exclusiva de los artistas a quienes se les aseguraba un pago mensual y los insumos para la elaboración de los grabados; ${ }^{46}$ la colección se publicó el año siguiente.

Aunque recurrieron a varias estrategias de representación utilizadas por Foxe como la figura del "testigo activo" y el recurso de la multitud, los 40 cuadros presentan características particulares significativas. En primer lugar, tal como quedó consignado en la portada de la obra, sus autores pretendían resguardar

45. Loades, "The Early Reception”, s. p.

46. Philip Benedict, Graphic History. The Wars, Massacres and Troubles of Tortorel and Perrissin (Ginebra: Droz, 2007). 


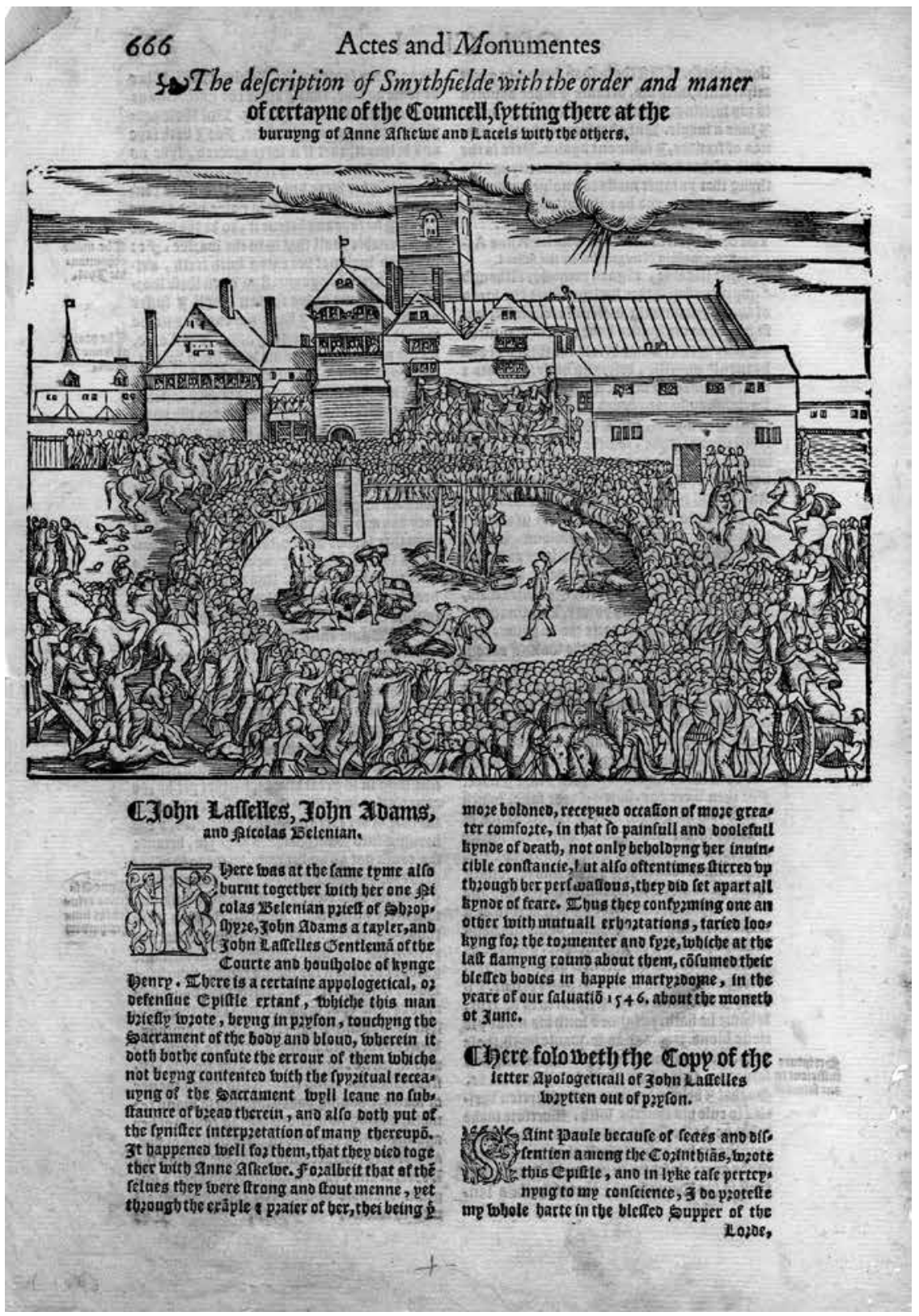

5. John Foxe, La descripción de Smythfielde con el orden y manera del innegable Consejo presente ante Anne Askew y Lacels entre otros que se calcinarían en la hoguera; grabado en madera, tomado de John Foxe, Acts and Monuments, siglo xvi, fol. 666. Londres, British Museum, núm. ref. I87I,I209.64 (C) The Trustees of the British Museum CC-BY-NC-SA-4.o. 
DOI: http://dx.doi.org/10.22201/iie.18703062e.2016.109.2578

la memoria de los acontecimientos: "para que la posteridad sea fielmente advertida, para que estas cosas [los hechos que ilustran los grabados] puedan estar siempre ante tus ojos". ${ }^{47}$ El que sólo "la verdad" sea digna de ser mostrada y recordada no es excepcional pues otros martirologios de la época se proponían objetivos similares; lo inusual en este caso es que se postula que la verdad sólo es posible si se preserva de las pasiones que conducen al engaño. Vemos aquí una voluntad manifiesta de contribuir a la comprensión de los acontecimientos.

En segundo lugar, la obra persigue la verdad histórica y lo hace por medio de unas imágenes que, lejos de limitarse a ilustrar el texto escrito, se presentan como emancipadas del mismo. ${ }^{4}$ En este marco, el espacio adquiere un protagonismo activo por medio de elementos como el fuego, el humo, las aguas agitadas, las murallas y los castillos destruidos, que dan cuenta del dramatismo de una escena, de la adversidad de una situación o de lo sorpresivo de un ataque (fig. 6).

Una tercera característica se vincula al interés de los artistas por ofrecer una síntesis clara de los sucesos, para lo cual recurrieron a imágenes panorámicas, perspectivas y vistas a vuelo de pájaro. En composiciones que resultan del entrecruzamiento de los registros cartográfico, teatral y pictórico (fig. 7), proponen imágenes que evidencian el uso de la perspectiva, los cortes transversales, las relaciones entre espacios públicos y privados, y la disposición de los personajes en patios, salones, castillos, periferias de ciudades y poblados, cuyas características se describen con detalle en busca de realismo y autenticidad.

La problematización del vínculo entre acontecimiento y representación da lugar a la cuarta característica de la obra. Las variaciones de los límites espaciales y temporales de las imágenes invitan a reflexionar sobre la naturaleza del suceso; un primer grupo de imágenes se distingue por recurrir a una escala "ampliada" en la que se incorpora la representación de decisiones o acontecimientos políticos vinculados a los hechos de violencia (fig. 7).

De manera opuesta, un segundo grupo de imágenes representa las prácticas de violencia con una visión "restringida" sin incluir ningún otro tipo de referencia (fig. 8). Este juego de escalas se desarrolla tanto en términos espaciales (res-

47. "Présentation générale de l'oeuvre de Tortorel et Perrissin", Dossier réalisé par le service éducatif de la Médiathèque du Grand Troyes, 2, consultado el Io de septiembre de 2016, www. cndp.fr/crdp-reims/fileadmin/documents/preac/patrimoine_mediatheque_troyes/Commentaire_des_gravures_BR.pdf.

48. Philip Benedict, Lawrence Bryant y Kristen Neuschel, "Graphic History: What Readers Knew and Were Taught in the 'Quarante Tableaux' of Perrissin and Tortorel”, French Historical Studies 28, núm. 2 (2005): 175-229. 
DOI: http://dx.doi.org/10.22201/iie.18703062e.2016.109.2578

RELIGIÓN, POLÍTICA Y ESPECTÁCULO

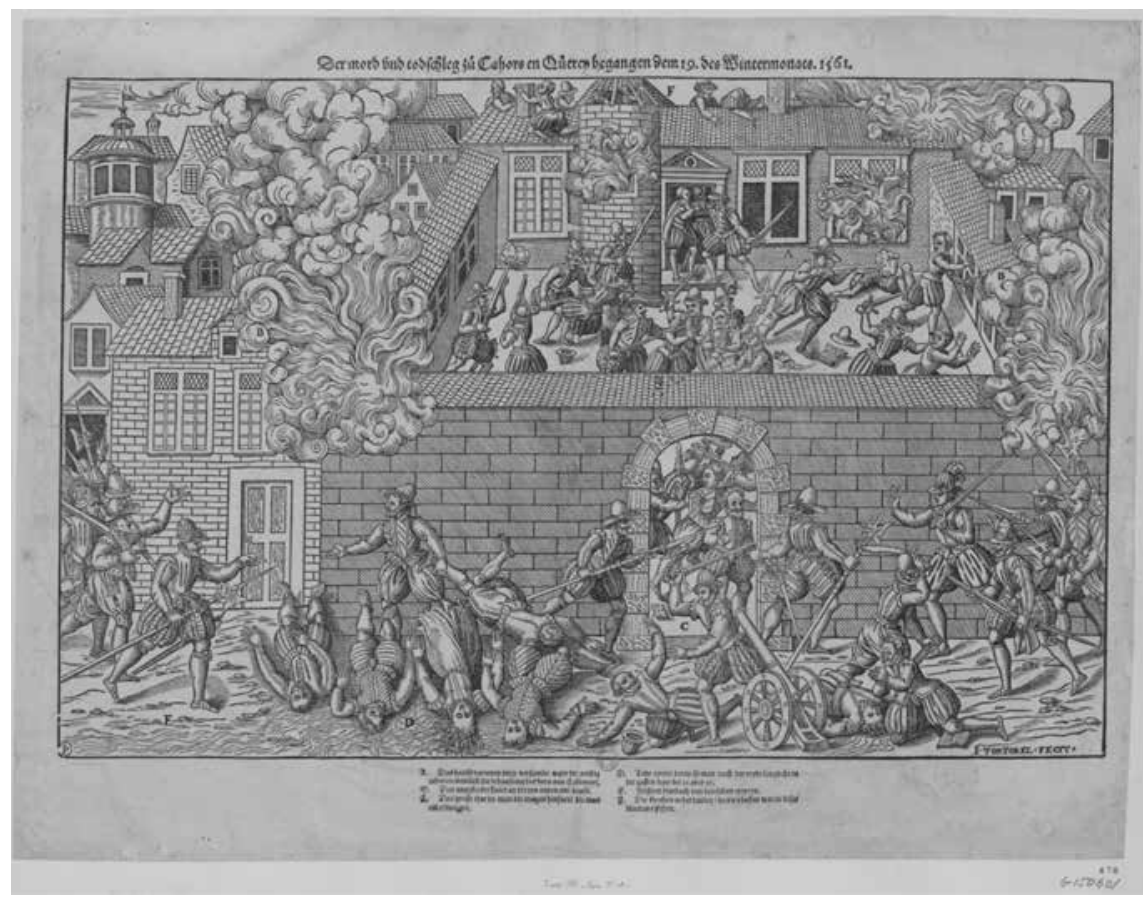

6. Jacques Tortorel, La matanza y asesinatos en Cahors, disputas que comenzaron el I9 del mes invernal de 1561 , s.i. 1570 , grabado en madera, $20 \times 27 \mathrm{~cm}$. (C) Bibliothèque Nationale de Francehttp://gallica.bnf.fr.

pecto a eventos ocurridos en distintos lugares) como temporales (con relación a sucesos de diferentes momentos); en uno y otro caso, y tanto en su versión expandida como restringida, las imágenes se componen mediante múltiples unidades de paisajes caracterizados por la sincronía representacional, una técnica común de la época, ${ }^{49}$ que consiste en descomponer el acontecimiento general de episodios puntuales. Las imágenes no presentan los hechos en una secuencia de sucesos cronológicamente ordenados ni se organizan en función del tiempo. Más bien, éstos se muestran respecto del espacio compositivo y la separación de las unidades se resuelve incorporando dichos episodios a una misma composición y resguardando así la idea de totalidad del acontecimiento.

49. Bucher ha denominado a un artificio similar el "método rotativo". Véase Bernadette Bucher, La Sauvage aux seins pendants (París: Hermann, 1977), 33-34. 
DOI: http://dx.doi.org/10.22201/iie.18703062e.2016.109.2578

II8

CARLOS ARTURO SALAMANCA VILLAMIZAR

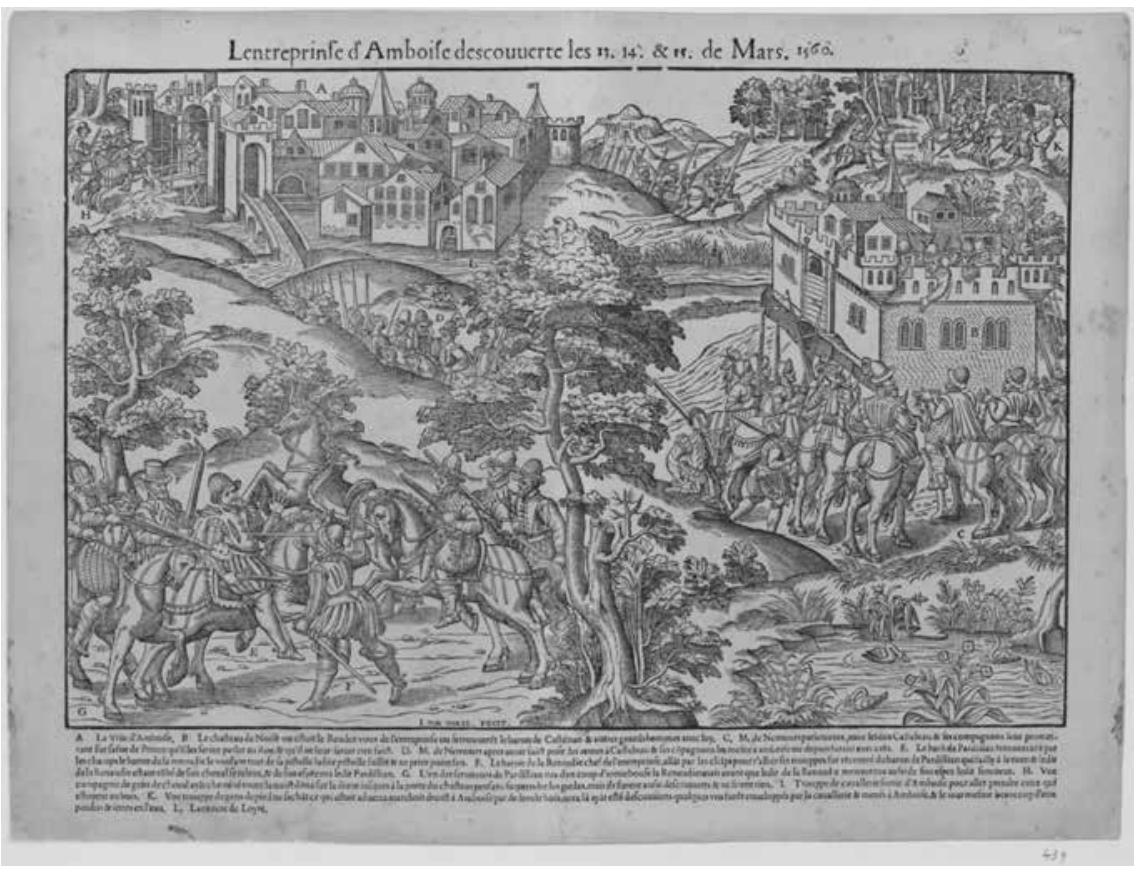

7. Jacques Tortorel, La conjura de Amboise descubierta el I3, I4 y IS de marzo de I560, I570, grabado en madera, $20 \times 27 \mathrm{~cm}$. (C) Bibliothèque Nationale de France-http://gallica.bnf.fr.

En La matanza y asesinatos en Cahors, disputas que comenzaron el ig del mes invernal de I56I, La conjura de Amboise descubierta el I3, I4 y I5 de marzo de I560 y en La derrota de la batalla de Moncontour se ejemplifica la versión expandida, en $\mathrm{La}$ masacre en Nismes en Languedoc el I de octubre de 1567 por la noche, la restringida. Para no extenderme describo solamente la figura 9 que constituye un punto intermedio y retoma elementos de ambos aspectos: desde el punto de vista del espacio la imagen registra lo que sucede en el tejado, los muros, la puerta o el lugar central de la construcción, en su perímetro, e incluso un poco más allá. En la sucesión temporal se han incluido imágenes sobre el inicio del ataque, las desdichas de un hombre, el terror de una mujer, la muerte en masa, el periplo de alguien que huye, y del cardenal de Lorraine, que, apoyado en el borde de un muro, observa a distancia la masacre. 


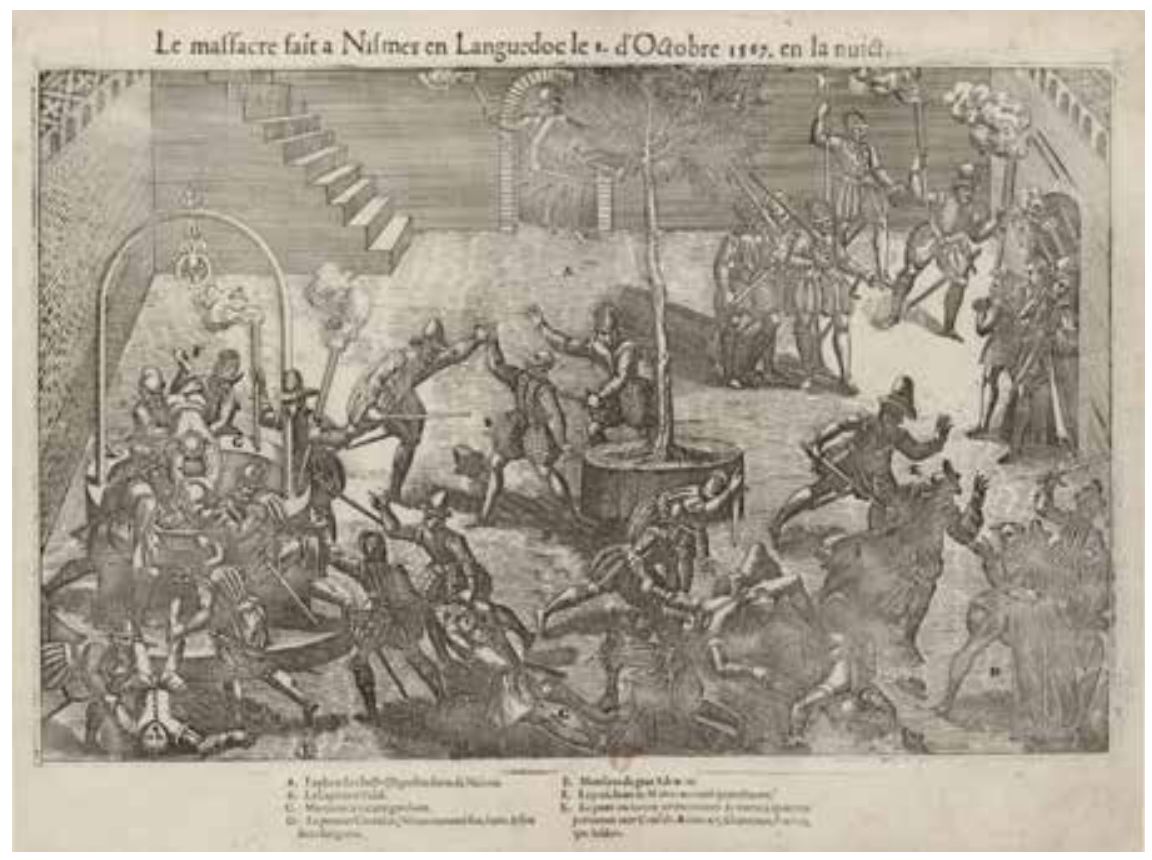

8. Jacques Tortorel, La masacre en Nismes en Languedoc el I de octubre de 1567 por la noche, 1570 , grabado en madera, $20 \times 27 \mathrm{~cm}$. (C) Bibliothèque Nationale de France-http://gallica.bnf.fr.

Quinta característica. A diferencia de la obra de Foxe que exhibe un claro posicionamiento frente a las tensiones religiosas, en Perrissin y Tortorel la verdad histórica se superpone a la lectura teológica. Para esto recurren a la construcción de acontecimientos históricos con ubicaciones espacio-temporales específicas, la incorporación en el título de cada grabado del lugar y la fecha de los acontecimientos, la identificación explícita de los protagonistas y, en general, de todos los episodios representados a partir de un sistema de referencias y notación por medio de letras (fig. 8).

Esta voluntad de historicidad se constata en la secuencia que puede establecerse entre las imágenes mismas. Los grabados refieren acontecimientos históricos sucedidos entre I559 y I570; de ellos, I2 son sobre los acontecimientos que llevaron a la primera guerra de religión en la primavera de 1562 , mientras que otro grupo de 15 versa sobre las tres primeras guerras de religión (I562-1563, I567-I568, y I568I570), el resto se dedica a ataques, emboscadas y otras confrontaciones. 
DOI: http://dx.doi.org/10.22201/iie.18703062e.2016.109.2578

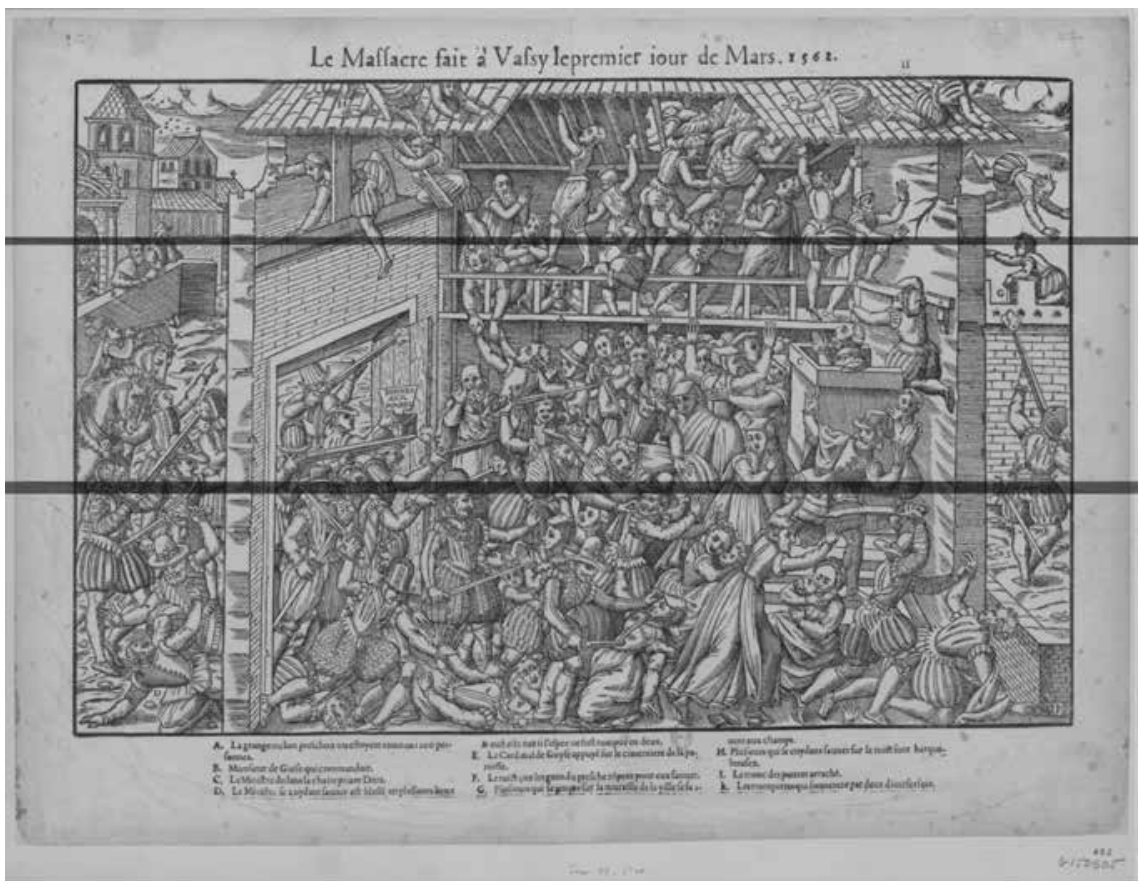

9. Jacques Tortorel, La masacre en Vassy el primero de marzo de 1562 [1569], I570, grabado en madera, $20 \times 27 \mathrm{~cm}$. (C) Bibliothèque Nationale de France-http://gallica.bnf.fr

Una sexta característica de los 40 cuadros que se deriva de la anterior se vincula con el posicionamiento de los artistas frente a la violencia. En su colección, Perrissin y Tortorel incluyeron un acontecimiento en el que la violencia es ejercida por el grupo religioso al que, en principio, pertenecen; se trata de la masacre de la Michelade en Nismes en la que un grupo de protestantes mató a I2O cristianos, tirándolos en pozos (fig. 8). El registro de este acontecimiento requiere del desplazamiento del énfasis en la emoción (la identificación con las víctimas, la descalificación moral de los otros en tanto victimarios) al de la comprensión del suceso por parte de sus realizadores. La narrativa subyacente aquí no es una crítica monolítica a la crueldad y los excesos de violencia de un otro visto como adversario. Más bien, se trata de una descripción que, alejándose de las perspectivas particulares de hechos singulares, propone leer las violencias más allá de las posiciones circunstanciales que católicos o 


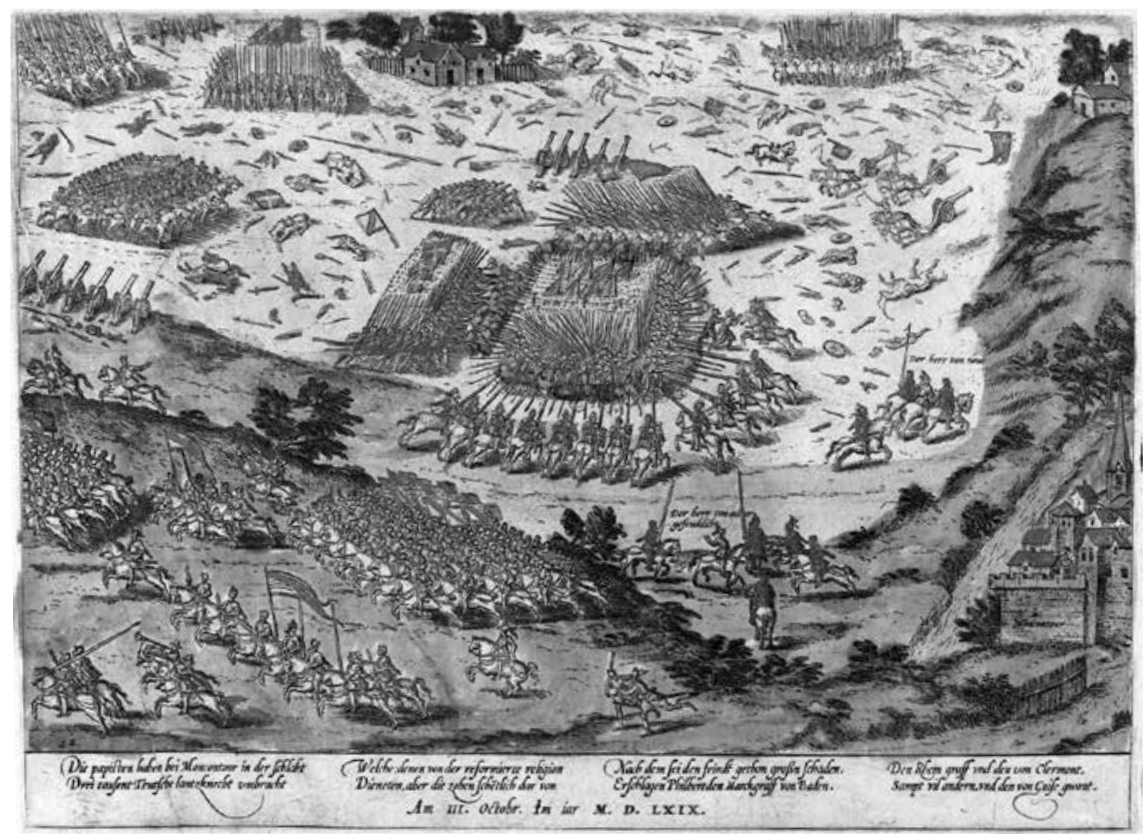

IO. Frans Hogenberg a partir de la obra de Tortorel y Perrissin, La derrota de la batalla de Moncontour, siglo XvI, aguafuerte, $20 \times 27 \mathrm{~cm}$. (C) Musée National du Château de Pau. Réunion des Musées Nationaux-www.photo.rmn.fr.

protestantes pueden ocupar en las casillas de victimarios y de víctimas. Así, los artistas enmarcan las violencias como un "enfrentamiento fratricida", una guerra entre "ejércitos franceses luchando el uno contra el otro" (fig. Io)..$^{\circ}$

Podría sugerirse que este cambio responde a razones prosaicas como las características del mercado editorial en expansión: haciendo uso de cierta neutralidad, la publicación alcanzaría un público tan internacional como multiconfesional. Asimismo, podría decirse que este cambio da cuenta de unas audiencias que, de la mano de la emergencia del pensamiento moderno, se despojaban poco a poco de la religión como marco interpretativo. Es posible afirmar también, que se vincula con lo antojadizo de la confesionalidad de dos artistas protestantes que apenas una década después de la publicación de

50. Benedict, Graphic History, 8. 
DOI: http://dx.doi.org/10.22201/iie.18703062e.2016.109.2578

$\mathrm{I} 22$

su obra, se adscribirían al catolicismo. Responder a este interrogante sobrepasa los objetivos de este trabajo. No obstante, es pertinente subrayar que la tesis de la secularización (del mercado, de las audiencias, de los marcos interpretativos, de los autores) dejaría sin explicar el éxito editorial que por los mismos años cosechaban los martirologios que movilizaban las pasiones religiosas. De igual manera, la conversión religiosa de los artistas protestantes podría interpretarse a la luz de la hostilidad que durante esos años encontraban los protestantes en el país galo al ser la masacre de San Bartolomé ocurrida en agosto de 1572 el evento emblemático de tal animadversión.

La obra trasciende el relato que sitúa la crueldad exclusivamente en el otro y que excluye a ese otro — violento, cruel, amenazante — de la comunidad de sentido en la que la verdad teológica predomina por sobre la histórica. Asimismo, con un discurso más descriptivo que propagandístico, las imágenes proponen una postura moderada, sin referencias emotivas o expresiones de autoexaltación..$^{\text {I }}$

La última característica tiene que ver con la noción de la autoría. En $L a$ derrota de la batalla de Moncontour (fig. Io) propongo al lector acceder a los 40 cuadros por medio de otro artista, el alemán Frans Hogenberg, quien elaboró sus obras a partir de las de aquéllos. Los mismos Perrissin y Tortorel se apoyaron en los trabajos de Jean Vredeman de Vries para componer algunas de sus obras y durante la época había "motivos" que eran retomados una y otra vez por artistas como François Dubois y Antoine Caron..$^{52}$ En este caso, la autoría se hace relativa en razón de los múltiples agentes que intervienen en la producción de la obra.

Interés por la verdad histórica, inteligibilidad de la violencia mediante las imágenes, entrecruce de registros representacionales, problematización del acontecimiento, voluntad de historicidad y desdibujamiento de los límites clásicos del autor son los aspectos que sobresalen de la obra de Perrissin y Tortorel. Me ocuparé ahora de la obra de Verstegan que a diferencia de los martirologios ya analizados se elaboró desde "el punto de vista católico".

5I. Benedict, Graphic History, 26.

52. Jean Ehrmann, "Massacre and Persecution Pictures in Sixteenth Century France", Journal of the Warburg and Courtauld Institutes, núm. 8 (1945): 197. 
DOI: http://dx.doi.org/10.22201/iie.18703062e.2016.109.2578

RELIGIÓN, POLÍTICA Y ESPECTÁCULO

Verstegan y $\mathrm{El}$ teatro de las crueldades. La crueldad es puesta en escena

Richard Rowlands, más conocido como Richard Verstegan o Verstegen, nació en Londres en I548. Hijo de un inmigrante alemán católico, su infancia y juventud estuvieron marcadas por experiencias personales que daban cuenta de la creciente hostilidad que los católicos encontraban en Inglaterra. Cuando cumplió 30 años, Verstegan ya había publicado panfletos denunciando la muerte y los sufrimientos de sacerdotes católicos en Inglaterra, en los que los reconocía como mártires; en I58I contribuyó para la elaboración de un panfleto sobre el jesuita Edmund Capion ahorcado y descuartizado en Londres por orden de la reina Isabel I de Inglaterra después de negarse a la apostasía. Descubierta su participación, fue desterrado. Entre 1581 y 1584 Verstegan vivió en Rouen, Reims y París, en donde hizo varias publicaciones similares. En 1584, fue arrestado en París a solicitud del embajador inglés, acusado de ofender a la reina misma de Inglaterra con sus imágenes; después de una breve temporada en prisión, ese mismo año viajó a Roma en donde se sometió a la protección del papa Gregorio XIII.

Allí, Verstegan encuentra una ciudad en la que por esos años se redescubrían las catacumbas y las reliquias de los primeros mártires, se reeditaba el martirologio romano y se incorporaba la figura del mártir en la renovación de muchas iglesias en el marco de la preparación de la celebración del Jubileo de 1600.53

Theatrum crudelitatum haereticor um nostri temporis (El teatro de las crueldades de los heréticos de nuestro tiempo) se publicó en 1587 en Amberes, convertida en bastión católico después de su reconquista por las tropas de Felipe II en 1585. La publicación cuenta con 29 imágenes elaboradas por el grabador flamenco Jan Wierix a partir de bosquejos de Verstegan. Las imágenes consisten en la reproducción de escenas de martirio y tormentos sufridos por los católicos, ${ }^{54} \mathrm{y}$ puede reconocerse como una respuesta a los martirologios de Crespin, Foxe, Perrissin y Tortorel.

El teatro fue una pieza fundamental en la iconografía católica de finales del siglo XVI y varios autores han señalado la continuidad entre El teatro y otros conjuntos artísticos como los frescos de Tommaso Cavalieri de la iglesia de San

53. Rodríguez G. de Ceballos, "El mártir, héroe cristiano", 89. Véase también Mónica Montoro Castillo, "Los oratorianos de San Felipe Neri y los inicios de la arqueología cristiana," CuPAUAM, núm. 34 (2008): 150.

54. El análisis se realizó a partir de la edición de 1592 del Theatrum crudelitatum haereticorum nostri temporis. 
DOI: http://dx.doi.org/10.22201/iie.18703062e.2016.109.2578

Estefano Rotondo en Roma, centrales en las representaciones del martirio del siglo XVI europeo. 55

Los grabados retoman el dispositivo dramático anunciado desde el título, explicitando el propósito de "hacer ver", y apelando a los protagonistas como joueurs, en la doble acepción del vocablo en francés de quien juega y de quien interpreta una pieza teatral.

Señores, hemos construido este teatro para presentarles las miserables tragedias que los herejes han actuado en nuestra Europa, y para hacerles ver aquello que han cometido y perpetrado [...] Ustedes los verán satisfaciéndose con derramar, regar y extraer la sangre humana, [y] bañarse, adobarse [y] regocijarse en la abundancia [...] Así verán a los herejes en este Teatro, sangrientos, humeantes, con mucho polvo, regresando de cazar católicos. ${ }^{56}$

El teatro propone entre las audiencias y los protagonistas de las imágenes una relación basada en la ejecución y la observación de un performance, apela a la emoción por encima de la comprensión del acontecimiento y privilegia el espacio teatral al geográfico. Por medio de estas operaciones se promueve un lector/espectador conmovido, escenografías imparciales e imágenes que proponen un argumento más dramático que explicativo sobre las violencias de los protestantes. ${ }^{57}$

Verstegan pone en escena la crueldad explícita y directa sin ambigüedades ni matices, en busca del efecto retórico que se deriva de una exposición reiterativa de actos de martirio. Pero a diferencia de Foxe y su interés en las víctimas y sus sufrimientos, en El teatro el acento está puesto en los victimarios y sus crueldades, siendo éstos y no los mártires los protagonistas: "Hemos construido este Teatro", dice el autor en la introducción, "con el fin de representarles las mise-

55. Véase, por ejemplo, Lestringant, "Témoignage et martyre”, II3 e Isabelle Engammare, "Le Théâtre des Cruautés des hérétiques de notre temps de Richard Verstegan", en Bibliothèque d'Humanisme et Renaissance 58, núm. I (1996): 305-307, 306.

56. "Messieurs, nous avons dressé ce théâtre afin de vous représenter les misérables tragédies que les hérétiques ont joué en notre Europe, et pour vous faire voir ce qu'ils ont commis et perpétré [...] Vous y verrez les joueurs se plaire à répandre, à verser, à tirer le sang humain, s'y baigner, s'y étuver, se réjouir en l'abondance [...] Tel verrez-vous les hérétiques sur ce théâtre, sanglants, fumeux, poudreux, revenant de la chasse de catholiques" (Verstegan, Théatre des Cruautés, 49,50, el subrayado es mío).

57. Lestringant y Moreau, "Overture", IO. 
rables tragedias que los heréticos han actuado en nuestra Europa, y para hacerles ver aquello que han cometido y perpetrado"..$^{8}$

En El teatro, lugares, tiempos y circunstancias pasan a un segundo plano; aunque en algunos casos los subtítulos de los grabados dan indicios de la localización de los acontecimientos, éstos son generales y poco precisos. Mientras que en la escena principal una larga sucesión de cuerpos son emasculados, colgados, despellejados, descuartizados y quemados. Monjes, sacerdotes o creyentes, las víctimas parecen ser siempre las mismas, abnegadas e inocentes. Los espacios anodinos y los cuerpos sufrientes constituyen el escenario propicio para resaltar el protagonismo de los victimarios que parecen acudir rutinariamente a cumplir su papel con la naturalidad de quien practica una tarea cotidiana, haciendo aún más explícita la violencia.

La profanación de símbolos y espacios religiosos es un tema que, inexistente en los martirologios protestantes analizados, hace su aparición en El teatro. En cinco de los 29 grabados los atacantes se empeñan en la destrucción de iglesias y objetos sagrados (fig. II).

La representación de la "poderosa violencia sacrílega" 59 en varias imágenes se refiere a la tensión entre los protestantes que propugnaban por la separación entre la "verdadera doctrina" y los objetos de representación, y los católicos que insistían en la imposibilidad de tal separación y calificaban la violencia iconoclasta como herética. La controversia acerca de la doctrina y su representación, parafraseando a Giorgio Agamben, era entre separar algo que no debía estar unido y en mantener unido aquello que originalmente lo había estado. ${ }^{60} \mathrm{Me}-$ diante la destrucción, los protestantes se proponían separar signo y significado

58. Lestringant, "Témoignage et Martyre", II9-I2O.

59. Todd Olson, "Pitiful Relics: Caravaggio’s Martyrdom of St. Matthew”, Representations 77, núm. I (2002): IO7-I42, I28.

6o. De acuerdo con Agamben, en la máquina del sacrificio, sagrado y profanado se representa un sistema de dos polos en los cuales transita un significado que aunque flotante, no deja de referirse a un mismo objeto. La formulación tiene que ver con dos operaciones: una consagratoria en la cual el poder es garantizado mediante la referencia a un modelo sagrado, y una profanatoria por la que se desactivan los dispositivos de poder. Ambas operaciones se caracterizan por una ambigüedad constitutiva. Tanto en la operación consagratoria como en la profanatoria persisten residuos, tanto de profanidad en toda cosa consagrada, como de sacralidad en cada objeto profanado. Esta persistencia de lo inacabado, de lo nunca definitivo, explica la necesidad de reiteración de toda operación. Una y otra vez, el martirologio se propone ya unir aquello que ha sido separado, ya separar aquello que ha sido unido. Véase Giorgio Agamben, Profanaciones, trads. Flavia Costa y Edgardo Castro (Buenos Aires: Adriana Hidalgo Editora, 2005), Ioo. 


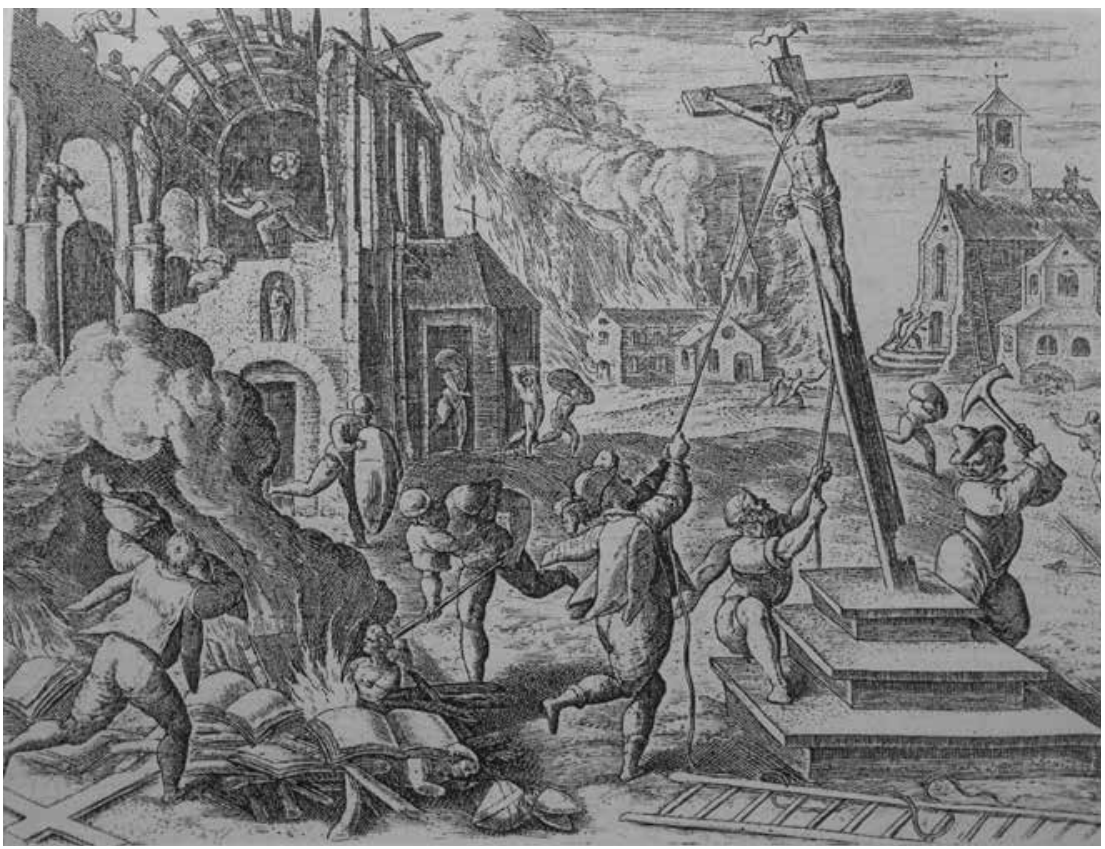

II. Anónimo, El nuevo fruto del Evangelio, 1588 [I557], I3, calcografía, I2 × I5 cm, atribuido en primer término a Verstegan; también a Wierix a partir de los bosquejos de Verstegan. (C) Bibliothèque Nationale de France-http://gallica.bnf.fr.

cuya unión les resultaba sacrílega y neutralizar así el signo que considerado sagrado, profanaba. Al reconocer tal destrucción como herética, los católicos mantenían dicha unión originaria.

La importancia acordada a la profanación se produce además en un contexto marcado por el redescubrimiento de las catacumbas romanas que puso de relieve las disputas por unir y separar: las reliquias con la sacralidad, los primeros mártires con aquellos que mueren en el presente a manos de sus enemigos religiosos, el inframundo de las catacumbas con la superficie, los primeros cristianos y las "últimas fronteras" en donde los misioneros se enfrentaban al martirio. ${ }^{6}$

6I. Carlos Salamanca Villamizar, "Herejes e infieles: imaginación etnográfica, experiencia histórica y prácticas comunicativas de la alteridad en la obra de De Bry", Revista Brasileira de História das Religióes 7, núm. I9 (2014): 9I-I06; Gérard Labrot, L'Image de Rome: une arme pour la Contre-Réforme, 1534-1677 (París: Champ Vallon, 1987). 


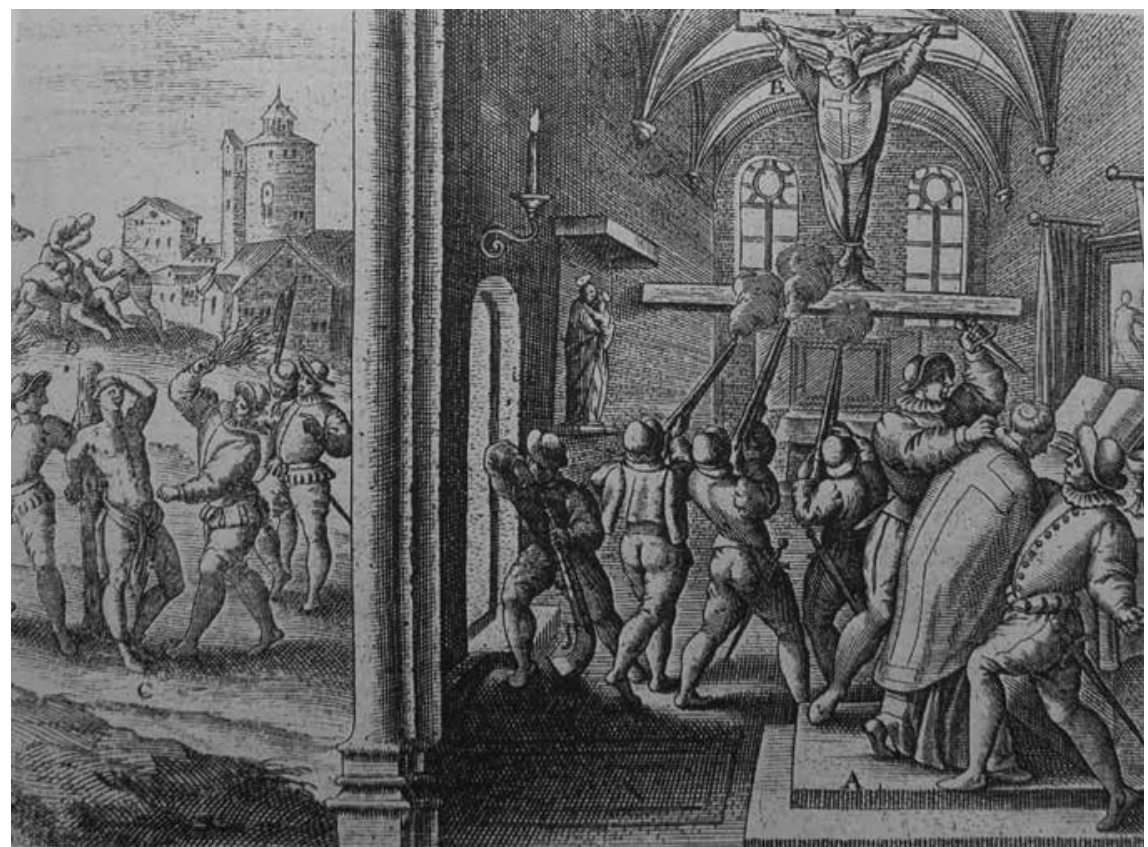

I2. Anónimo, Terribles crimenes cometidos en Francia por los hugonotes, I588 [I557], 45, calcografía, $\mathrm{I} 2 \times 15 \mathrm{~cm}$, atribuido en primer término a Verstegan; también a Wierix a partir de los bosquejos. (C) Bibliothèque Nationale de France-http://gallica.bnf.fr.

En varios grabados las víctimas son sorprendidas y ultimadas en sus casas, bajo sus doseles, en sus camas. En esta inscripción de la violencia en el espacio cotidiano, sobresale el uso recurrente de los perpetradores de lo que tienen a mano para infligir muerte y dolor: el fuego de una chimenea se convierte en una hoguera, un pozo de agua en el vacío al que son arrojadas las víctimas, un crucifijo en una iglesia en una cruz para crucificar (fig. I2). La violencia que avanza sobre el espacio de lo cotidiano se extiende hasta los lugares más íntimos; actos de profanación de los cuerpos se ilustran en 2I de los 29 grabados. La comprensión "amplia" de la profanación se vincula con la doctrina que declara la sacralidad del cuerpo en tanto casa de Dios y templo primordial. ${ }^{62}$

62. Levítico 19: 28, Corintios 6:19. 


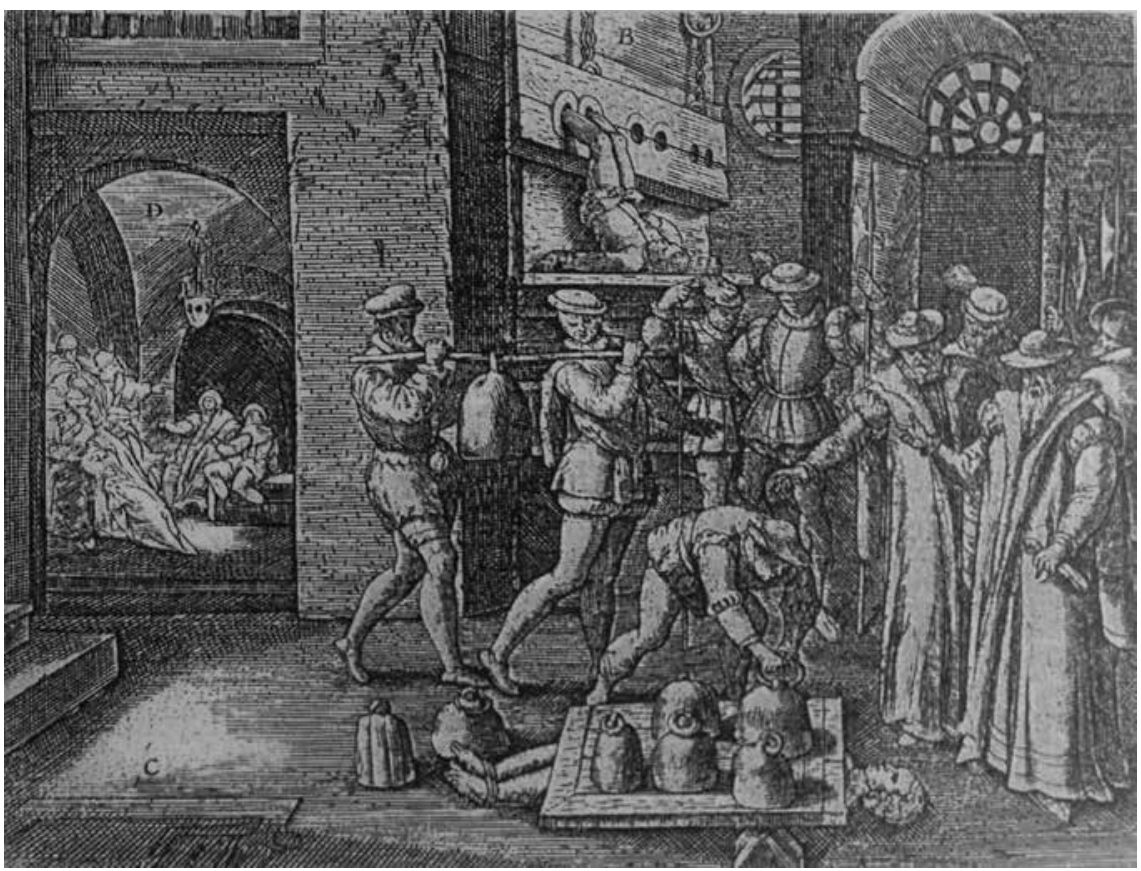

13. Anónimo, Persecución de los protestantes contra los católicos en Inglaterra, I588 [1557], 77, calcografía, I $2 \times 15 \mathrm{~cm}$, atribuido en primer término a Verstegan; también a Wierix a partir de los bosquejos de Verstegan. (C) Bibliothèque Nationale de France-http://gallica.bnf.fr.

$\mathrm{Al}$ inscribirse en iglesias, casas y cuerpos, la profanación atraviesa toda la obra; en los Terribles crimenes cometidos en Francia por los hugonotes (fig. I2), por ejemplo, se ilustra el interior de una iglesia en la que los victimarios disparan sus fusiles contra el cuerpo de un sacerdote que ha sido crucificado en un crucifijo, sintetizando las tres formas de profanación (de espacios, de cuerpos, de objetos).

Un número importante de grabados (22/29) ilustran la segunda característica: la exhibición de algún tipo de conocimiento en el arte de infligir dolor. Las imágenes incluyen el uso de armas como cuchillos, espadas, hachas, picas, lanzas $\mathrm{y}$ venablos, o instrumentos como martillos, tenazas y pinzas puestas al servicio del martirio. Aunque presentes en las obras de otros artistas ya analizados, en Verstegan se destacan las técnicas diseñadas y creadas específicamente con el fin de matar y torturar, como la elaboración de nudos, formas específicas de efectuar los cortes y otros tratamientos del cuerpo de las víctimas (fig. 13). 
Además de cadalsos y horcas, en aproximadamente la mitad de los grabados (I4/29), aparecen máquinas como cepos y caballetes con rodillos, y otras más complejas construidas con pesas, poleas y manivelas. Estas imágenes reflejan el interés creciente en las máquinas e instrumentos que se expandía por entonces en Europa, inaugurado por Jacques Besson en 1578 con un tratado con ilustraciones de todo tipo de máquinas; ${ }^{63}$ con una misma vocación ilustrativa el sacerdote italiano Antonio Gallonio publicó otra obra en la que describe diversos tipos de instrumentos y técnicas de martirio. ${ }^{64}$

Respecto a la tercera característica de la obra es preciso evocar los martirologios protestantes en donde la muchedumbre tenía una presencia activa. En varios grabados de Verstegan (19/29) la masa también tiene un papel protagónico aunque con otra particularidad: en este caso, más que de "masa" sería más preciso hablar de un cuerpo cohesionado, que sigue una organización, una secuencia y un orden. Como se observa en los Horribles crímenes perpretados en Francia por los hugonotes (fig. I4), cinco grupos de personas ejecutan acciones coordinadamente; a lo lejos fusilan, allí arrancan dientes, aquí lancean, un poco más acá, torturan con fuego; hay quien inicia y preserva el fuego, hay quien detiene a la víctima, y hay quien se encarga del martirio propiamente dicho. Aquí no hay ejércitos como en los 40 cuadros ni ejecuciones públicas relativamente institucionalizadas como en Acts and Monuments; más bien, un colectivo de personas que se organiza para martirizar.

Esto nos lleva a la cuarta característica; en las imágenes los victimarios parecen causar tormentos como resultado de la repetición rutinaria y la violencia parece formar parte de un programa sistemáticamente repetido, sin muchas variaciones. Es en este marco donde puede ubicarse la imagen en la que unos hombres juegan a la petanca con la cabeza de sus víctimas combinándose la tortura rutinaria, la banalización del dolor y la muerte, la complicidad, la confraternidad y la emergencia de lo lúdico en tanto "inversión de lo sagrado". 65

63. Se trata de Theatrum instrumentorum machinarum, consultado el I de diciembre de 2013, www.sil.si.edu/DigitalCollections/Hst/Besson/besson-introduction.htm.

64. Antonio Gallonio, Tratatto degli Instrumenti di martirio e delle varie manière di martirizare (Grenoble: Jerôme Millon, 2002 [I59I]). Al respecto, véase por ejemplo: Alfonso Rodríguez G. de Ceballos, "El mártir, héroe cristiano. Los nuevos mártires y la representación del martirio en Roma y en España en los siglos XVI y XVII", Quintana: Revista de estudios do Departamento de Historia da Arte, núm. I (2002): 84-99.

65. Agamben, Profanaciones, Ioo. 


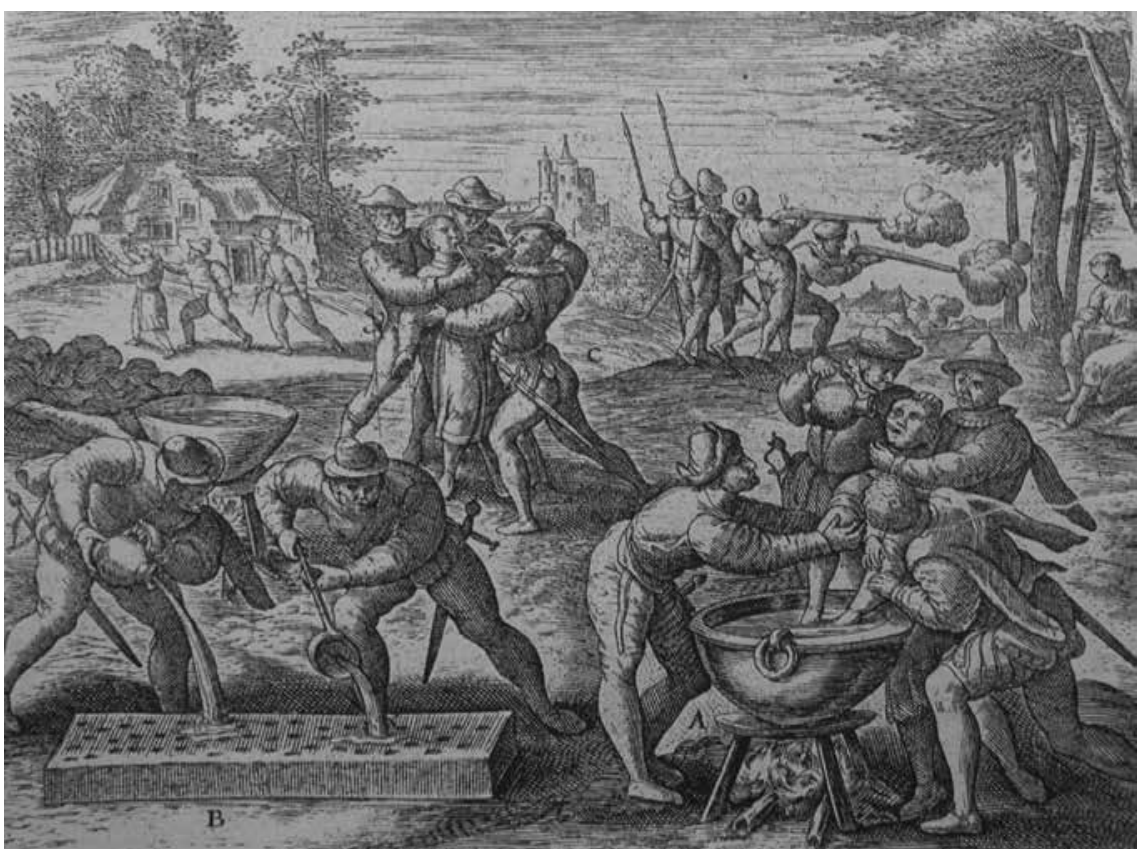

I4. Anónimo, Horribles crimenes perpetrados en Francia por los hugonotes, I588 [I557], 39, calcografía, $12 \times 15 \mathrm{~cm}$, atribuido en primer término a Verstegan; también a Wierix a partir de los bosquejos de Verstegan. (C) Bibliothèque Nationale de France-http://gallica.bnf.fr.

La quinta característica es la de El teatro en tanto marco interpretativo versátil. Todos los participantes que aparecen en los grabados, sean víctimas, victimarios o testigos, y sin importar la acción que lleven a cabo, son anónimos. Este anonimato resalta los suplicios y las torturas realizadas por encima de sus protagonistas. Tal característica, sumada al recurso de lugares genéricos, hace que la imagen pueda pensarse como la representación de violencias no sólo ocurridas en diferentes lugares sino en contra de diferentes personas. ${ }^{66}$

66. Tal maleabilidad dialoga con el hecho de que múltiples grupos en otros contextos históricos o políticos y a pesar de la distancia histórica o geográfica, incorporaron el martirio y otras figuras religiosas en diversos tipos de procesos identificatorios. Stievermann, por ejemplo, se refiere a la incorporación de estas figuras por congregaciones alemanas en la región de Pensilvania a mediados del siglo XviII. Jan Stievermann, "A 'Plain, Rejected Little Flock': The Politics of Martyrological Self-Fashioning among Pennsylvania's German Peace Churches, 1739-1765", The William and 
Para sintetizar, he identificado seis características principales: la condición de un género difuso derivado de su localización a medio camino entre el registro histórico y el testimonial, la forma directa y sin matices en que la crueldad es puesta en escena, las prácticas de profanación como dimensión del martirio, el conocimiento en el arte de infligir dolor, la dimensión colectiva y cohesionada de los perpetradores, la ejecución rutinaria del martirio, y la forma en que $E l$ teatro se convierte en una herramienta interpretativa flexible y en instrumento apto para dar cuenta de violencias ocurridas en diversos lugares.

Concluiré mencionando que en El teatro se incluye la imagen del ataque a un barco que transportaba misioneros católicos hacia el Brasil por parte del corsario Jacques Soria en 1570 en el que murieron 39 jesuitas. En efecto, de la misma forma que las tensiones religiosas trascendieron las fronteras europeas expresándose en obras como las de fray Bartolomé de las Casas, ${ }^{67}$ temas ligados a la Conquista y el descubrimiento del Nuevo Mundo como la evangelización hicieron su aparición en obras que hacían referencia a las guerras de religión europeas. ${ }^{68}$

\section{Comentarios finales}

He analizado la relación entre prácticas de violencia y representación interesándome en las prácticas del martirio y en sus narrativas pues su potencia reside no

Mary Quarterly, Third Series, 66, núm. 2 (2009): 287-324, 289. Véase también Carlos Salamanca Villamizar, "Saberes geográficos, tensiones de alteridad y teatros del martirio en las cartografías jesuíticas del Nuevo Mundo", Revista Española de Antropología Americana, 5 (en prensa).

67. Bartolomé de las Casas, Historia de las Indias (Madrid: Aguilar, 1927) [1552]).

68. Durante el siglo XvI varias congregaciones, pero principalmente franciscanos y jesuitas, impulsaron la constitución de una verdadera "cultura del martirio", en un contexto en el que la expansión europea daba lugar a una apertura mundial del campo misional. En el siglo XvII las narrativas del martirio se expandieron en todos los rincones de la extensa labor misional y la figura de los mártires se inscribió en distintos espacios en el territorio americano. Acerca de la forma en que el vínculo entre las prácticas del martirio y las prácticas misioneras impulsó la proyección del tropo del martirio en las narrativas sobre la conquista religiosa, véase por ejemplo: Salamanca Villamizar, "Das catacumbas às últimas fronteiras", 270-275; para otros análisis, Artur Barcelos, "Os Jesuítas e a ocupaçao do espaço platino nos séculos Xvir e XviII", Revista Complutense de Historia de América 26 (2000): 93-I16; Christophe Giudicelli y Pierre Ragon, "Les Martyrs ou la Vierge? Frères martyrs et images outragées dans le Mexique du Nord (xvième-xvirème siècles)", Nuevo Mundo. Mundos Nuevos, 2005, consultado el I8 de noviembre de 2013, http://nuevomundo. revues.org/6I5 y Maria Cristina Gómez-Géraud, "Le Théâtre des premiers martyrs japonais: la leçon de théologie", Revue de Sciences Humaines, núm. 269 (2003): 175-187. 
DOI: http://dx.doi.org/10.22201/iie.18703062e.2016.109.2578

I32

sólo en la reproducción del rito primordial, sino en su reproducción en el presente y su proyección hacia el futuro. El martirologio, tal como lo he analizado aquí, es un género de representación de la violencia cuya especificidad se deriva de su relación con la expansión editorial; como consecuencia de este vínculo emergen cuestiones como los mecanismos y los procesos de reproducción, la censura, los problemas de traducción, y en un lugar especial las audiencias que lejos de ser estables pueden ser simultáneamente vagas y bien delimitadas, imaginadas y reales, constituidas o en proceso de constitución.

Pero los martirologios analizados también obtienen la especificidad de su papel en las guerras de religión, deviniendo campo y herramienta en la disputa por la hegemonía religiosa. Los martirologios se enfrentan al desafío de convertirse en marcos interpretativos de los acontecimientos en una verdadera guerra por la representación ejecutada mediante la representación misma. En este contexto el martirologio puede proponerse dar cuenta de los sufrimientos de las víctimas, narrar "la verdad histórica" o poner en escena y denunciar la crueldad de los victimarios. A cada uno de estos propósitos le corresponden formas específicas de describir los acontecimientos, de elaborar las narrativas de las prácticas de violencia las que, a su vez, están acompañadas de operaciones y estrategias compositivas. El martirologio así abordado permite complementar las investigaciones que privilegian el análisis de "los medios", con interrogantes acerca de las mediaciones. Las relaciones sociales de producción y uso de discursos y representaciones en contextos particulares son el resultado de diversas mediaciones; el martirologio "media" entre las audiencias y los acontecimientos de violencia y propone interpretaciones, significaciones y sentidos específicos.

No obstante, enfatizar la dimensión comunicativa del martirologio y las mediaciones a las que da lugar no es sugerir que el martirio se limite a ser una práctica discursiva, que el mártir se restrinja a ser el emisor de un discurso religioso o los actos de violencia de un metalenguaje a ser interpretado. Las guerras de religión dejaron experiencias de terror, desplazamiento y muerte y los mismos artistas elaboraron sus narrativas de la religión y la violencia en un campo geopolítico en tensión; Foxe en Estrasburgo, Perrissin y Tortorel en Ginebra, Verstegan en Roma, todos ellos narraron la violencia religiosa desde sus propias experiencias de exilio, persecución y refugio.

El martirologio ubica el acto del martirio en coordenadas espacio-temporales y en una narrativa más amplia; tanto dicha ubicación como dicha narrativa se articulan circunstancialmente en diversas prácticas: fechas de martirios con calendarios y rituales conmemorativos, lugares de martirio con geografías 
religiosas y prácticas de peregrinación, figuras de mártires y ejercicios de imitación. A partir del análisis de tres martirologios emblemáticos de la primera modernidad he demostrado que por intermedio de las representaciones de la violencia no sólo se describen los acontecimientos sino que al hacerlo se producen y afianzan identidades colectivas en torno a ciertos valores, principios y marcos interpretativos. \&

N.B. Versiones preliminares de este trabajo se presentaron en el seminario Espacio, Historia y Poder, llevado a cabo entre 2012 y 2014 en universidades de Argentina y Colombia. Agradezco a Germán Rey del Centro Ático de la Pontificia Universidad Javeriana de Bogotá y a Guillermo Wilde de la Universidad de San Martín la invitación a exponer algunos avances de esta investigación. Asimismo doy gracias a los participantes, quienes con sus comentarios y preguntas me impulsaron a revisar parte de los argumentos que aquí se presentan, así como a los evaluadores de esta revista por sus estimulantes observaciones. Asimismo doy gracias también a Mark Greengrass del proyecto "John Foxe" por su colaboración, así como al equipo editorial de la revista Anales del IIE por su minucioso trabajo. 